Prepared in cooperation with Utah State University

\title{
Update on Regulation of Sand Transport in the Colorado River by Changes in the Surface Grain Size of Eddy Sandbars Over Multiyear Timescales
}

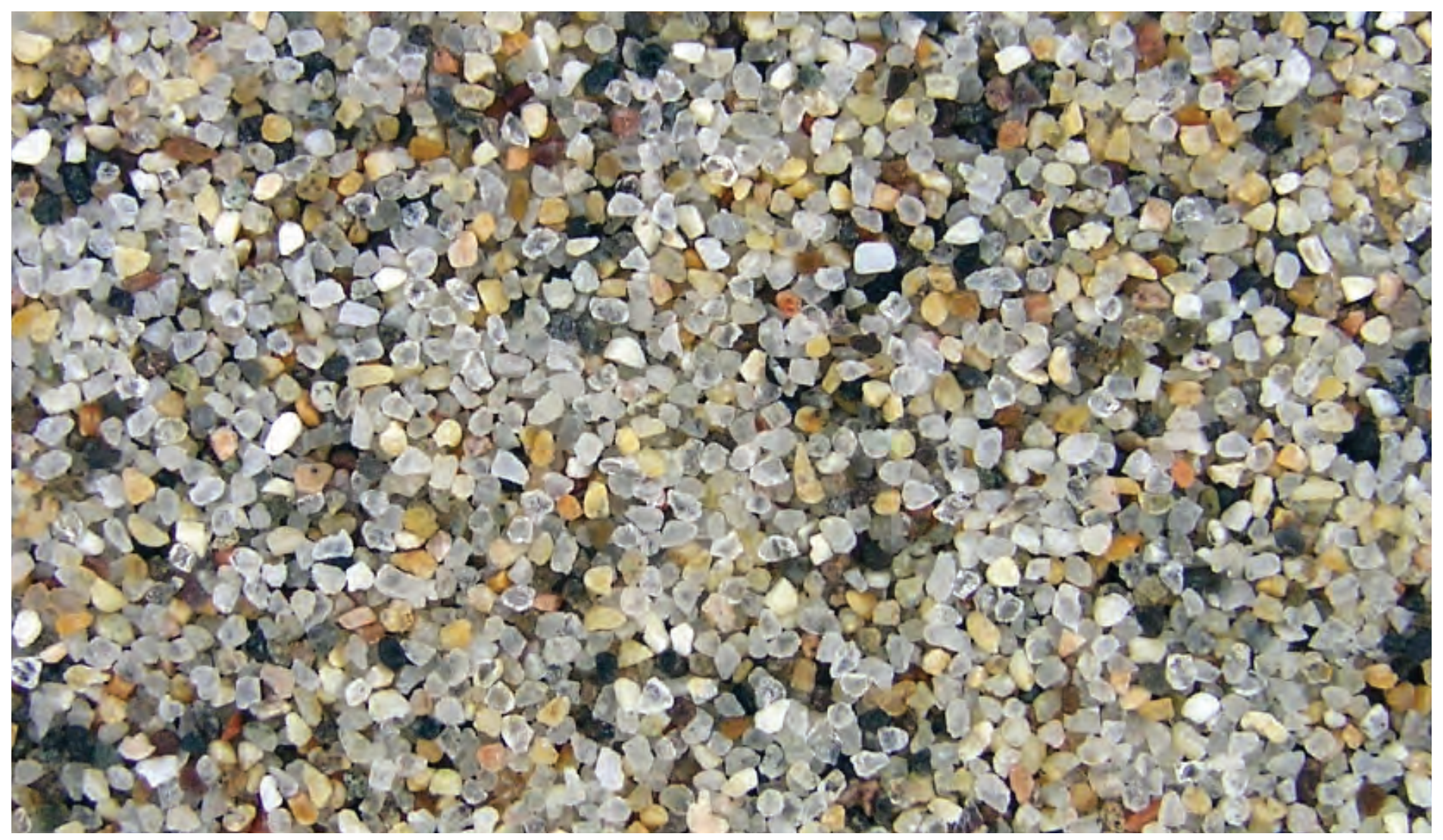

Scientific Investigations Report 2008-5042 



\section{Update on Regulation of Sand Transport in the Colorado River by Changes in the Surface Grain Size of Eddy Sandbars Over Multiyear Timescales}

By David J. Topping, David M. Rubin, and John C. Schmidt

Prepared in cooperation with Utah State University

Scientific Investigations Report 2008-5042 


\section{U.S. Department of the Interior DIRK KEMPTHORNE, Secretary}

\section{U.S. Geological Survey \\ Mark Meyers, Director}

\section{U.S. Geological Survey, Reston, Virginia: 2008}

For product and ordering information:

World Wide Web: http://www.usgs.gov/pubprod

Telephone: 1-888-ASK-USGS

For more information on the USGS--the Federal source for science about the Earth, its natural and living resources, natural hazards, and the environment:

World Wide Web: http://www.usgs.gov

Telephone: 1-888-ASK-USGS

Any use of trade, product, or firm names is for descriptive purposes only and does not imply endorsement by the U.S. Government.

Although this report is in the public domain, permission must be secured from the individual copyright owners to reproduce any copyrighted materials contained within this report.

Suggested citation:

Topping, D.J., Rubin, D.M., and Schmidt, J.C., 2008, Update on regulation of sand transport in the Colorado River by changes in the surface grain size of eddy sandbars over multiyear timescales: U.S. Geological Survey Scientific Investigations Report 2008-5042, 24 p.

Cover: Sand grains on the surface of a Colorado River eddy sandbar (USGS photo by David Rubin). 


\section{Contents}

Abstract

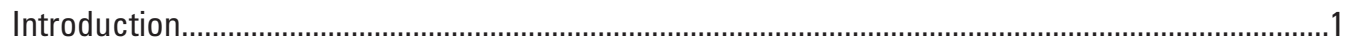

Goal of This Study

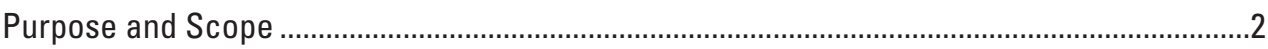

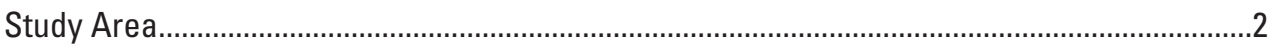

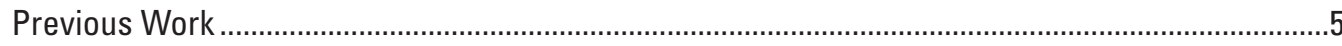

Shorter Term Coupled Changes in Sand Transport and Bed-Sand Grain Size in the Channel....6

Changes in Bed-Sand Grain Size Inferred From $\beta$ Analyses of Suspended-Sand Data ..........6

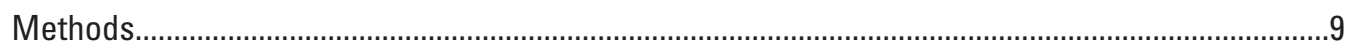

$\beta$-Inferred Changes in the Surface Grain Size of Bed Sand as a Function of Elevation...........9

Changes in Sand Grain Size on the Channel Bed and on Eddy-Sandbar Surfaces as

Determined From Direct Observations .....................................................................10

Results and Discussion......................................................................................................11

$\beta$-Inferred Changes in the Surface Grain Size of Bed Sand as a Function of Elevation.........11

Changes in Sand Grain Size on the Channel Bed...............................................................13

Changes in the Surface Grain Size of Sand on the Lowest Elevation Part of Eddy Sandbars...17

Changes in the Surface Grain Size of Sand on the Mid- and High-Elevation Parts of Eddy

Sandbars............................................................................................................17

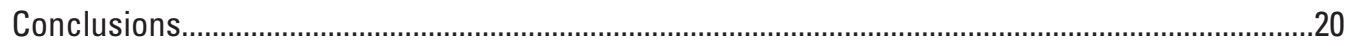

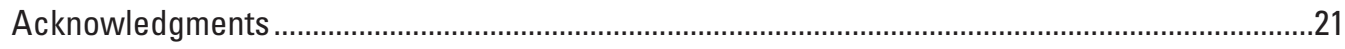

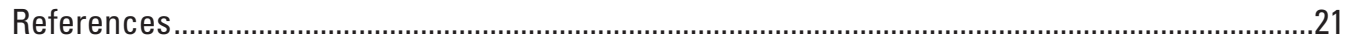

\section{Figures}

1. Map of the study area showing the locations of selected U.S. Geological Survey gaging stations, sampled eddy sandbars, and trenches excavated through 1983 flood deposits .................................................................................................................

2. Photograph showing typical eddy sandbar in Marble Canyon, the right-bank sandbar in the fan-eddy complex at RM22...................................................................................

3. Hydrograph of the Colorado River at the Lees Ferry gage between 1982 and $2001 \ldots \ldots . . . .5$

4. Graph showing mean of the median grain sizes $\left(D_{50}\right)$ of the channel-bed sand over the central two-thirds of the cross section at the Grand Canyon gage in June-July 1983, during the postdam flood of record .........................................................................

5. Graph showing $\beta$ time series computed from all 1983-2000 suspended-sand data collected at the Lower Marble Canyon and Grand Canyon gages ...................................8

6. Diagrams showing a typical fan-eddy complex in Marble and upper Grand Canyons indicating and two cross sections showing the approximate elevations of the three discharge intervals used in the $\beta$ analysis

7. Graphs showing $1983-2000 \beta$ time series from figure 5 segregated into three discharge intervals

8. Graphs showing $\beta$ as a function of the discharge of water at the Lower Marble Canyon gage and the Grand Canyon gage 
9. Graphs showing temporal variation in sand grain size on the channel bed at the Lower Marble Canyon and Grand Canyon gages from 1983 through 2000.

10. Graphs showing longitudinal and temporal variation in sand grain size on the channel bed between the Lees Ferry and Grand Canyon gages, from 1984 through 2000, determined from pipe-dredge data.....

11. Graphs showing longitudinal and temporal variation in sand grain size on the lowest elevation part of eddy sandbars in Marble Canyon as determined from pipe-dredge data

12. Graphs showing mean of the median grain sizes $\left(D_{50}\right)$ of the sand on eddy-sandbar surfaces at mid and high elevations in Marble and upper Grand Canyons from 1982 through 2000 and normalized median grain size $\left(D_{50}\right)$ of sand measured vertically through four 1983 flood deposits in Marble and upper Grand Canyons.

13. Diagram of an idealized cross section showing an eroding eddy sandbar capped by a coarsening-upward 1983 flood deposit.

\section{Tables}

Table 1. Dates, locations, numbers of samples, and sources of data for sampled eddy-sandbar surfaces in Marble and upper Grand Canyons, Ariz

\section{Conversion Factors}

[Inch/Pound to SI]

\begin{tabular}{|c|c|c|}
\hline Multiply & By & To obtain \\
\hline \multicolumn{3}{|c|}{ Length } \\
\hline inch (in.) & 25.4 & millimeter $(\mathrm{mm})$ \\
\hline foot $(\mathrm{ft})$ & 0.3048 & $\operatorname{meter}(\mathrm{m})$ \\
\hline mile (mi) & 1.609 & kilometer $(\mathrm{km})$ \\
\hline \multicolumn{3}{|c|}{ Flow rate } \\
\hline cubic foot per second $\left(\mathrm{ft}^{3} / \mathrm{s}\right)$ & 0.02832 & cubic meter per second $\left(\mathrm{m}^{3} / \mathrm{s}\right)$ \\
\hline
\end{tabular}

[SI to Inch/Pound]

\begin{tabular}{lll}
\hline \multicolumn{1}{c}{ Multiply } & \multicolumn{1}{c}{ By } & To obtain \\
\hline & Length & \\
millimeter $(\mathrm{mm})$ & 0.03937 & inch (in.) \\
meter $(\mathrm{m})$ & 3.281 & foot $(\mathrm{ft})$ \\
kilometer $(\mathrm{km})$ & 0.6214 & mile $(\mathrm{mi})$ \\
\hline & Flow rate & \\
cubic meter per second $\left(\mathrm{m}^{3} / \mathrm{s}\right)$ & 35.31 & cubic foot per second $\left(\mathrm{ft}^{3} / \mathrm{s}\right)$ \\
\hline
\end{tabular}

Horizontal coordinate information is referenced to the North American Datum of 1983 (NAD 83). 


\title{
Update on Regulation of Sand Transport in the Colorado River by Changes in the Surface Grain Size of Eddy Sandbars Over Multiyear Timescales
}

\author{
By David J. Topping, David M. Rubin, and John C. Schmidt
}

\section{Abstract}

In settings where the transport of sand is partially or fully supply limited, changes in the upstream supply of sand are coupled to changes in the grain size of sand on the bed. In this manner, the transport of sand under the supply-limited case is "grain-size regulated." Since the closure of Glen Canyon Dam in 1963, the downstream reach of the Colorado River in Marble and Grand Canyons has exhibited evidence of sand-supply limitation. Sand transport in the river is now about equally regulated by changes in the discharge of water and changes in the grain sizes of sand on the channel bed and eddy sandbars. Previous work has shown that changes in the grain size of sand on the channel bed (driven by changes in the upstream supply of sand owing to both tributary floods and high dam releases) are important in regulating sand transport over timescales of days to months. In this study, suspended-sand data are analyzed in conjunction with bed grain-size data to determine whether changes in the sand grain size on the channel bed, or changes in the sand grain size on the surface of eddy sandbars, have been more important in regulating sand transport in the postdam Colorado River over longer, multiyear timescales. The results of this study show that this combined theory- and field-based approach can be used to deduce which environments in a complicated setting are most important for regulating sediment transport. In the case of the regulated Colorado River in Marble and upper Grand Canyons, suspended-sand transport has been regulated mostly by changes in the surface grain size of eddy sandbars.

\section{Introduction}

The transport of a given size of sediment is controlled by (1) hydraulics (that is, the boundary shear-stress and velocity fields) and (2) the upstream supply of that size class. When the upstream supply of the given size class is sufficiently large, changes in hydraulics are the dominant controllers of transport. This case can be referred to as the equilibrium-upstreamsupply case. When the upstream supply of the given size class is not sufficiently large to maintain transport in equilibrium with the hydraulics, changes in the upstream supply of that size class result in changes in the transport of that size class. This latter case is typically referred to as the supply-limited case. In most situations, the transport of a given size of sediment is probably controlled by a combination of changes in the hydraulics and changes in the upstream supply. In the equilibrium-upstream-supply case, no substantial changes in the grain-size distribution of the bed sediment occur, whereas in the supply-limited case, substantial changes in the grain-size distribution of the bed sediment accompany changes in the upstream supply of sediment (Topping and others, 2000a, 2000b). Sediment transport under the equilibrium-upstream-supply case is "flow-regulated," and sediment transport under the supply-limited case is "grain-size regulated" (Rubin and Topping, 2001).

Rubin and Topping (2001) developed a generalized analytical technique for determining the relative degrees to which sediment transport in a given setting is regulated by changes in bed-sediment grain size and changes in hydraulics. They determined that both processes are equally important in controlling sand transport in the Colorado River downstream from Glen Canyon Dam in Grand Canyon. In addition, they found that changes in bed-sand grain size can play important roles in regulating sand transport not only in bedrock-canyon rivers, but also in alluvial rivers, such as the Mississippi River.

In this paper, the dam-regulated Colorado River is examined to determine the relative roles of different parts of the bed in regulating sand transport. Sand occurs in two key environments on the bed of this river. It occurs in the channel as patches on gravel, colluvium, and bedrock, and also in eddies as sandbars that may be more than several meters thick. Although the sand in eddies is typically thicker than the sand on the bed of the channel, it probably covers less area because eddies represent only about 20 percent of the area of the riverbed (Schmidt and others, 2004; Hazel and others, 2006). As described in this paper, $\beta^{1}$ analyses of suspended-sand data suggest that the bed environment, which

${ }^{1}$ Screen readers for the visually impaired will interpret the symbol "beta" as "b". 
is the dominant regulator of sand transport in the Colorado River, has fined over the past several decades. To determine which riverbed environment, channel or eddy, is the dominant regulator of sand transport, $\beta$ is calculated for discrete riverdischarge intervals, and all available surface grain-size data from the channel and eddy bed environments are analyzed. These analyses show that the smallest part of the bed, that is the eddy sandbars, is the dominant regulator of sand transport in this river. This approach of using suspended-sediment data in conjunction with field observations of surface grain-size change in different bed environments should be useful in other settings to determine whether sediment transport is regulated by the sediment comprising large portions of the bed, or by the sediment found in discrete environments that might comprise only a small part of the bed.

\section{Goal of This Study}

Sand transport in the postdam Colorado River is regulated by both changes in bed-sand grain size and changes in the discharge of water. Previous studies have concluded that changes in the sand grain size on the channel bed are the dominant regulator of sand transport in the Colorado River in Marble and upper Grand Canyons over timescales of days to months. The goal of this study is to evaluate the relative roles of the sand on the channel bed and the sand on the surface of eddy sandbars in regulating sand transport in the Colorado River in Marble and upper Grand Canyons over longer multiyear timescales.

\section{Purpose and Scope}

The results of this study were originally presented in Topping and others (2005). However, a typographical error in Rubin and Topping (2001) resulted in incorrect computations of $\beta$ in Topping and others (2005). The nature of this typographical error is described in Rubin and Topping (in press) and herein. This error adversely affected the $\beta$ analyses in Topping and others (2005), resulting in an incorrect reduction in the $\beta$-inferred magnitude of change in bed-sand grain size during the study period. The conclusions of Topping and others (2005) are strengthened by using correct $\beta$ values in the $\beta$ analyses.

The purpose and scope of this paper, therefore, is to present an updated version of Topping and others (2005) by using the correct values of $\beta$ in all analyses.

\section{Study Area}

The study area is the Colorado River in Marble and upper Grand Canyons (fig. 1). Discharge and sediment data from the following U.S. Geological Survey (USGS) gaging stations are analyzed: Colorado River at Lees Ferry, Ariz., station number 09380000 (herein referred to as the Lees Ferry gage); Colorado River above Little Colorado River near Desert View, Ariz., station number 09383100 (herein referred to as the
Lower Marble Canyon gage); and Colorado River near Grand Canyon, Ariz., station number 09402500 (herein referred to as the Grand Canyon gage). By convention, locations along the Colorado River are referred to by river mile (RM), as measured downstream from the Lees Ferry gage (Stevens, 1983). Marble Canyon extends $99 \mathrm{~km}$ from the Lees Ferry gage to the mouth of the Little Colorado River at RM 61.5; Grand Canyon extends $346 \mathrm{~km}$ from the mouth of the Little Colorado River to the Grand Wash Cliffs at RM 276 (below the upstream end of Lake Mead reservoir). The upstream $42 \mathrm{~km}$ of Grand Canyon, from the mouth of the Little Colorado River to the Grand Canyon gage at RM 87.4, is herein referred to as upper Grand Canyon. The study area begins $25.5 \mathrm{~km}$ downstream from Glen Canyon Dam, which impounds the Colorado River to form Lake Powell reservoir and has regulated the discharge of water in the study area since its closure in March 1963 (Topping and others, 2003). Closure of the dam has greatly reduced the supply of sand to the study area. The only substantial supplier of sand to the upstream end of the study area is now the Paria River, which supplies about 6 percent of the predam sand load at this location (Topping and others, 2000a).

The longitudinal profile of the Colorado River in Marble and Grand Canyons is characterized by long, gently sloping pools separated by short, steep drops in rapids (Leopold, 1969; Magirl and others, 2005). The banks of the river are composed mostly of talus and bedrock, with lesser amounts of sand and finer material (Howard and Dolan, 1981). The rapids in which most of the elevation loss occurs are formed by debris fans composed of coarser sediment delivered to the Colorado River by debris flows and floods from relatively small tributaries (Cooley and others, 1977; Webb and others, 1989; Melis and others, 1994). These debris fans give rise to the dominant geomorphic element in this reach, the fan-eddy complex (Schmidt and Rubin, 1995). The typical fan-eddy complex consists of a backwatered pool in the channel upstream from the debris fan, constricted flow through a rapid over the toe of the debris fan, and a large expansion in flow area downstream from the debris fan where the downstream flow separates from the bank to form a lateral recirculation eddy along the bank (fig. 2). Sandbars form in the eddy and are largely composed of sand deposited from suspension (Howard and Dolan, 1981; Rubin and others, 1990; 1994; Schmidt, 1990; Schmidt and Graf, 1990). If the upstream supply of suspended sand is sufficient, sandbars may fill most of the eddy (Wiele and others, 1996).

Though only a small percentage of the river area is composed of eddies, the total area of sand in eddies is only about 33-50 percent less than the total area of sand on the bed of the channel. Analyses of historical aerial photography and recent surveys indicate that about 20 percent of the river in Marble Canyon is composed of lateral recirculation eddies (Schmidt and others, 2004; Hazel and others, 2006). Side-scan-sonar data collected in the study area between 1994 and 2000 suggest that, on average, the channel bed is composed by area of 40 percent finer gravel (pebbles and cobbles of probable fluvial origin), 20-30 percent sand, 20-30 percent bedrock, and 10-20 percent large, immobile boulders that are either 


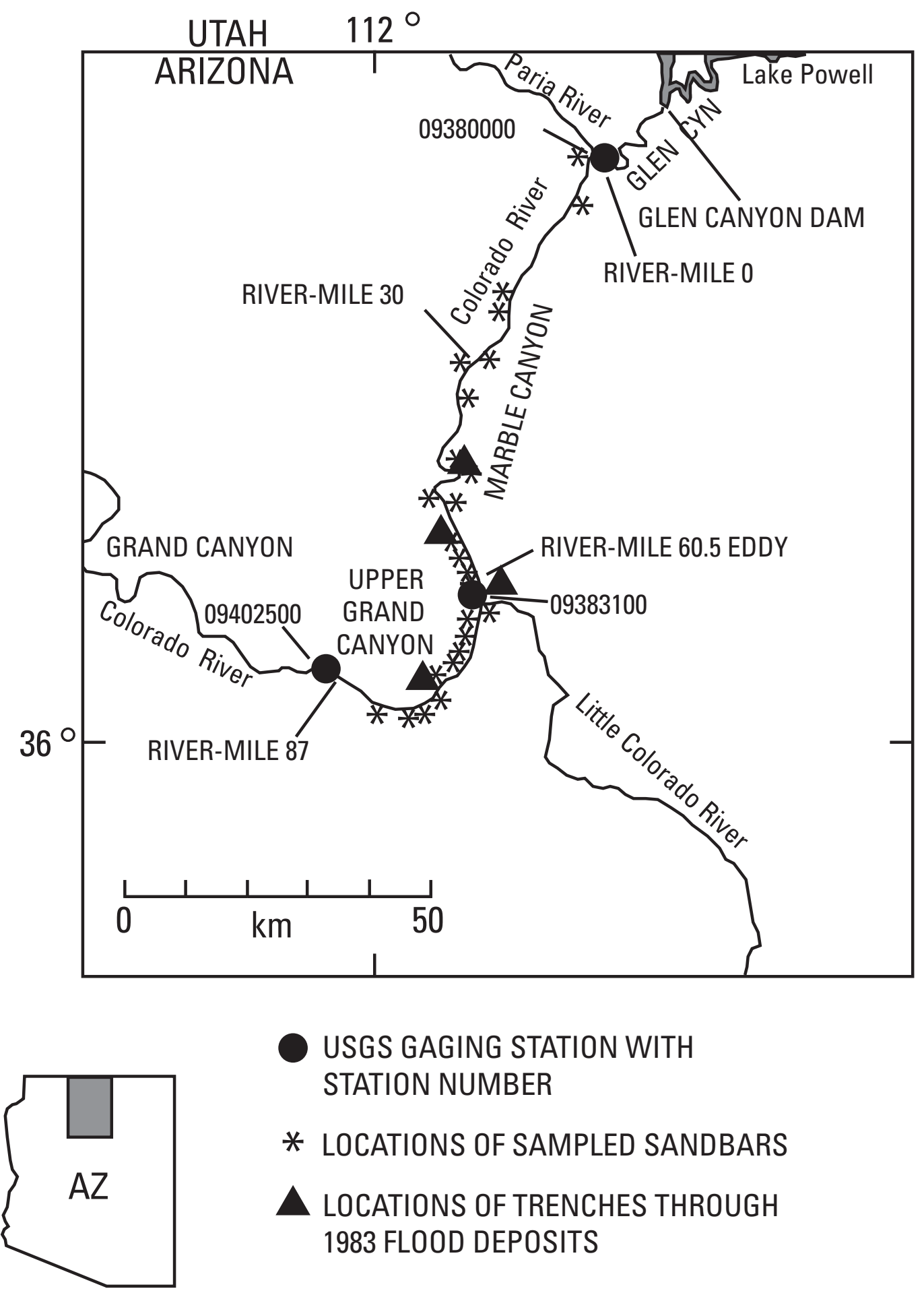

Figure 1. Map of the study area showing the locations of selected U.S. Geological Survey gaging stations, sampled eddy sandbars, and trenches excavated through 1983 flood deposits. 


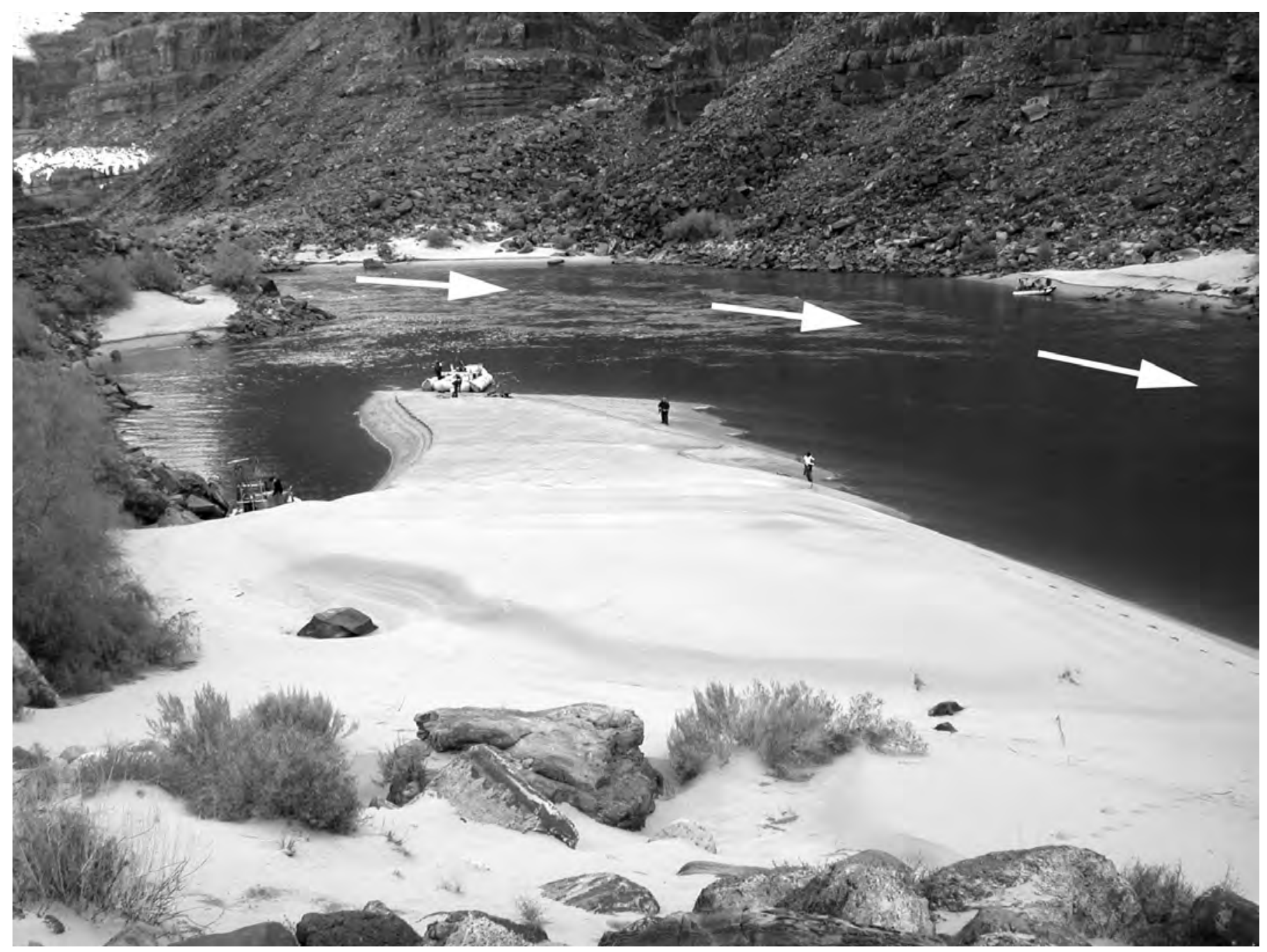

Figure 2. Photograph showing typical eddy sandbar in Marble Canyon, the right-bank sandbar in the fan-eddy complex at RM 22. White arrows indicate direction of flow in the channel; the discharge of water is $227 \mathrm{~m}^{3} / \mathrm{s}$. This sandbar is completely inundated at a discharge of approximately $1,200 \mathrm{~m}^{3} / \mathrm{s}$.

derived from tributaries or from the hillslopes and cliffs adjacent to the river (Anima and others, 1998; Wong and others, 2003; Schmidt and others, 2007). These data also suggest that, on average, sandbars occupy at least 60 percent of the eddy area, with the remainder of the eddy area composed of finer gravel or boulders. Thus, the area of sand in eddies is equivalent to about 12 percent of the total river area, and the area of sand in the channel is equivalent to about 16-24 percent of the total river area.

Although it begins 20 years after closure of Glen Canyon Dam, the study period 1983-2000 is the first multiyear postdam period with suspended- and bed-sand data adequate for this study. The analyses presented in this paper require time series of suspended-sand concentration and grain size (preferably from more than one location), and time series of bed-sand grain size from multiple locations and environments. The study period includes both the largest postdam flood $\left(2,750 \mathrm{~m}^{3} / \mathrm{s}\right.$ peak discharge $)$, which occurred in 1983 , and one of the longest postdam periods of sustained low discharge, which occurred in 2000 (fig. 3). The period from 1983 through 1986 was characterized by higher than average dam releases because of full reservoir conditions in Lake Powell. The period from 1987 through July 1991 was characterized by large daily fluctuations in discharge for power generation. Beginning in August 1991, dam releases were constrained in an attempt to minimize the downstream effects of dam operations (National Research Council, 1996). In March-April 1996, an experimental 7-day controlled flood with a peak discharge of $1,270 \mathrm{~m}^{3} / \mathrm{s}$ (the 1996 controlled flood) was released from the dam (Webb and others, 1999). In November 1997, a second experimental dam release was conducted consisting of a 2-day, $890-\mathrm{m}^{3} / \mathrm{s}$ powerplant-capacity dam release (Topping and others, 2000b). In 2000, a third experimental dam release was conducted consisting of 3 months of constant $227-\mathrm{m}^{3} / \mathrm{s}$ discharge between two 4-day powerplant-capacity flows (Schmidt and others, 2007). 


\section{Previous Work}

Beginning in the 1970s, concerns were raised about the effect of Glen Canyon Dam on the downstream ecosystem of the Colorado River in Marble and Grand Canyons (Dolan and others, 1974). Sandbar erosion downstream from the dam led to the early sediment-transport and geomorphologic studies of Dolan and others (1974), Howard (1975), Laursen and others (1976), and Howard and Dolan (1981). Dolan and others (1974) and Laursen and others (1976) concluded that, under normal powerplant releases from Glen Canyon Dam, the transport capacity of the river exceeded the supply of sand, and that the eddy sandbars would gradually erode away. In contrast to the results of these earliest studies, Howard and Dolan (1981), Randle and Pemberton (1987), Andrews (1990, 1991), and the U.S. Department of the Interior (1995) concluded that the tributary supply of sand downstream from the dam exceeded the transport capacity of the river under normal releases from the dam. These early sediment budgets relied on stable relationships between the discharge of water and sand transport. Following the experimental 1996 controlled flood, Topping and others (2000b) showed that, because the grain size of the sand on the channel bed changes substantially over time in response to both tributary activity and dam releases, stable relationships between the discharge of water and sand transport do not exist. Topping and others (2007) determined that changes in bed-sand grain size dominated over changes in bed-sand area in regulating suspended-sand concentration in both the predam (that is, natural) and postdam Colorado River at the Grand Canyon gage. Rubin and Topping (2001) concluded that, under typical powerplant releases from the dam, sand transport in the Colorado River is equally regulated by changes in bed-sand grain size and changes in hydraulics. From their analysis of suspended-sand data alone, however, it is impossible to know which riverbed environment, channel or eddy, was most important in regulating sand transport.

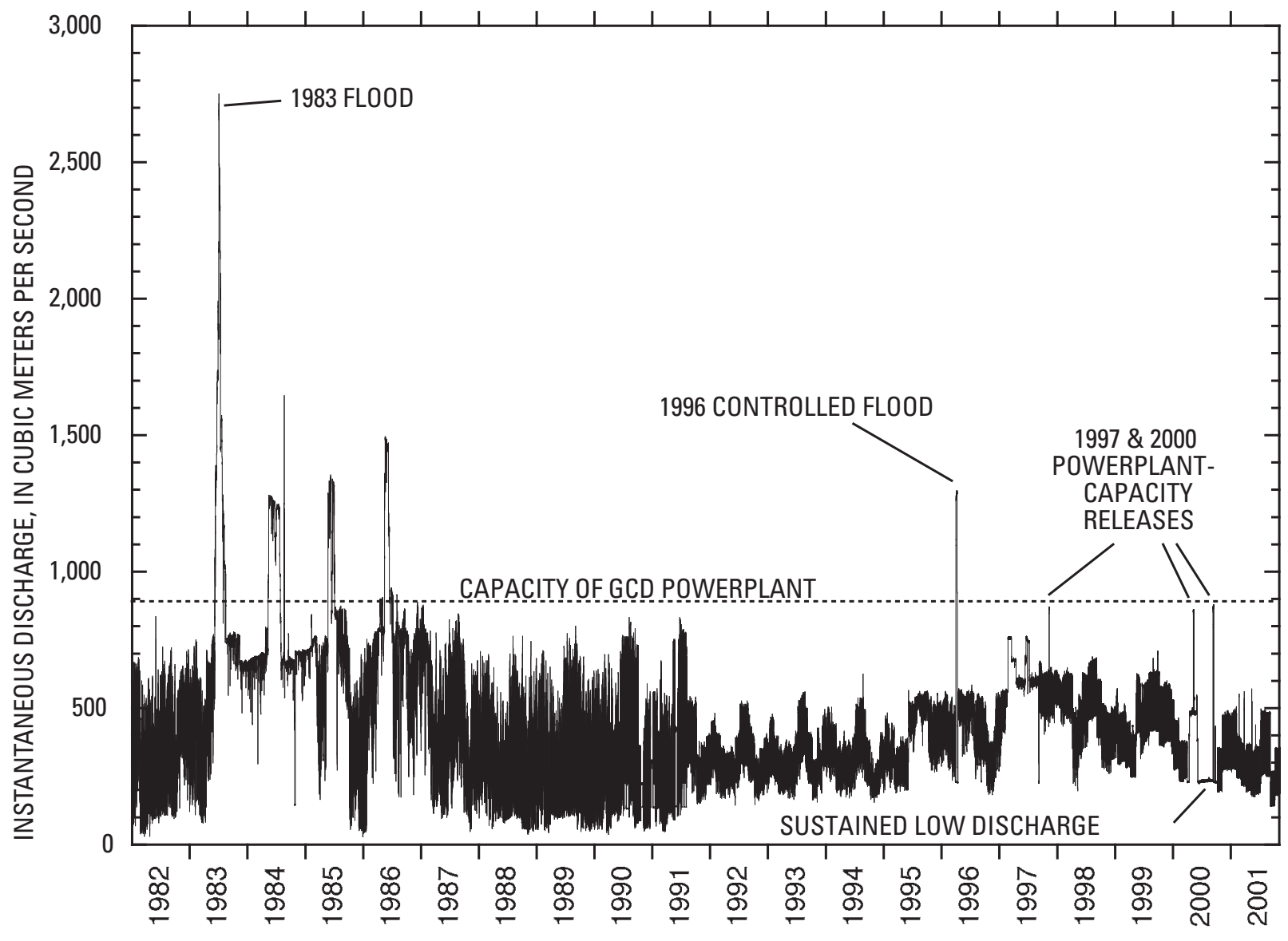

CALENDAR YEAR

Figure 3. Hydrograph of the Colorado River at the Lees Ferry gage between 1982 and 2001. Shown are the capacity of the Glen Canyon Dam (GCD) powerplant, the1983 flood (that is, the postdam flood of record), the 1996 controlled flood, the three 1997 and 2000 powerplant-capacity flows, and the 3 months of sustained low discharge during June-August 2000. 
Rubin and others (2002) analyzed recent sand-transport and geomorphic data and determined that the sand budget for the study area was negative during the previous several years of normal powerplant releases from Glen Canyon Dam. Topping and others (2000a) showed that, given the uncertainties in the sediment budget constructed using USGS historical daily sediment-transport data, one could not conclude that tributary-supplied sand was stored in the Colorado River in Marble and upper Grand Canyons for more than a few months. Flynn and Hornewer (2003) showed that the amount of sediment decreased in 55 of 57 cross sections surveyed repeatedly by the USGS between 1992 and 1999. Additionally, Schmidt and others (2004) showed that, between the mid-1980s and 2000, the amount of sand in the channel and eddies in Marble and upper Grand Canyons decreased by about 25 percent. More recently, Hazel and others (2006) estimated that, by volume, between 51 percent and 94 percent of the sand in Marble Canyon is stored in eddies, and that, as suggested by Schmidt (1999), eddies are the primary source of sand deposited at higher elevations during high dam releases. Thus, under normal dam releases over multiyear timescales, the sand budget of the Colorado River in Marble and upper Grand Canyons is negative, and most of the sand in multiyear storage occurs in eddy sandbars that are getting smaller over time. This result suggests that, although the area of sand in eddies is only about 50-67 percent of the area of sand in the channel, the sand stored in the eddy sandbars may play a dominant role in regulating sand transport in the postdam Colorado River over longer multiyear timescales.

\section{Shorter Term Coupled Changes in Sand Transport and Bed-Sand Grain Size in the Channel}

Recent work on the role that bed-sand grain size plays in regulating sand transport in the Colorado River has focused on the channel. Over shorter timescales, the grain size of the sand on the channel bed evolves quickly in response to large inputs of sand from the tributaries and in response to high releases from Glen Canyon Dam (Topping and others, 2000b). Because the median size of the sand supplied by tributaries is about $1 / 4$ to $1 / 2$ of the median size of the sand typically found in the channel bed, tributary-supplied sand is more mobile than the sand on the channel bed. Therefore, newly input sand travels downstream in the Colorado River as an elongating sediment wave in the suspended load, bedload, and bed sediment. As the front of a sediment wave propagates downstream, the bed of the channel fines, and suspended-sand concentrations increase in response to the enriched upstream supply of finer sand. Under moderate and higher powerplant releases from Glen Canyon Dam, these sediment waves propagate downstream quickly. Following the passage of a wave front, the sand on the bed is winnowed, and suspended-sand concentrations decrease in response to the depletion of the upstream supply of finer sand. Observations made by Topping and others (2000b) in Marble Canyon during 1998 and 1999 suggest that the sand on the channel bed can coarsen to its pre-tributary-input antecedent condition within about 6 months during moderate powerplant releases.

High clearwater releases from Glen Canyon Dam cause the sand on the channel bed to coarsen rapidly. During the 1996 controlled flood, which reached a peak release of $1,270-\mathrm{m}^{3} / \mathrm{s}$, the sand on the channel bed and in suspension coarsened by about a factor of 1.5 as the suspended-sand concentrations decreased (Rubin and others, 1998; Topping and others, 1999. 2000b). Though the Grand Canyon gage was the only place where measurements of bed-sand grain size were made during this flood, the systematic progressive coarsening and depletion of the sand in suspension were observed everywhere measurements were made (spanning a streamwise distance of over $170 \mathrm{~km}$ ). During the $2,750-\mathrm{m}^{3} / \mathrm{s}$ flood released from Glen Canyon Dam in 1983, the sand on the channel bed at the Grand Canyon gage coarsened by about a factor of 2 (fig. 4). As during the 1996 controlled flood, the Grand Canyon gage was the only location where bed-sand grain-size measurements were made during the peak part of the 1983 flood (Garrett and others, 1993). Unlike measurements made during the 1996 controlled flood, however, measurements of suspended-sand concentration and grain size were not measured at any location until the receding limb of the 1983 flood.

\section{Changes in Bed-Sand Grain Size Inferred from $\beta$ Analyses of Suspended-Sand Data}

Between 1983 and 2000, there were many more measurements of suspended-sand concentration and grain size made at the Lower Marble Canyon and Grand Canyon gages than there were direct measurements of the grain size of the sand on the bed of the river. Thus, it is advantageous to use the suspended-sand data to infer temporal changes in bedsand grain size. Furthermore, because suspension processes in the river effectively provide an average sample of the sand on the upstream bed of the channel and the underwater parts of the eddy sandbars, an appropriate analysis of the suspended-sand data can yield information on changes in the grain size of the sand on the surface of the channel bed and eddy sandbars upstream from the suspended-sand measurement location. Rubin and Topping (2001) developed such a technique to analyze suspended-sediment data based on theory and tested this technique against data from flumes and rivers. Their parameter $\beta$ is a nondimensional measure of the average bed-surface grain size that interacts with the suspended sand in the flow. $\beta$ uses the concentration and grain size of the sand in suspension to compute the average upstream grain size of the sand on the bed of the channel and the underwater parts of the eddy sandbars. $\beta$ is defined as 

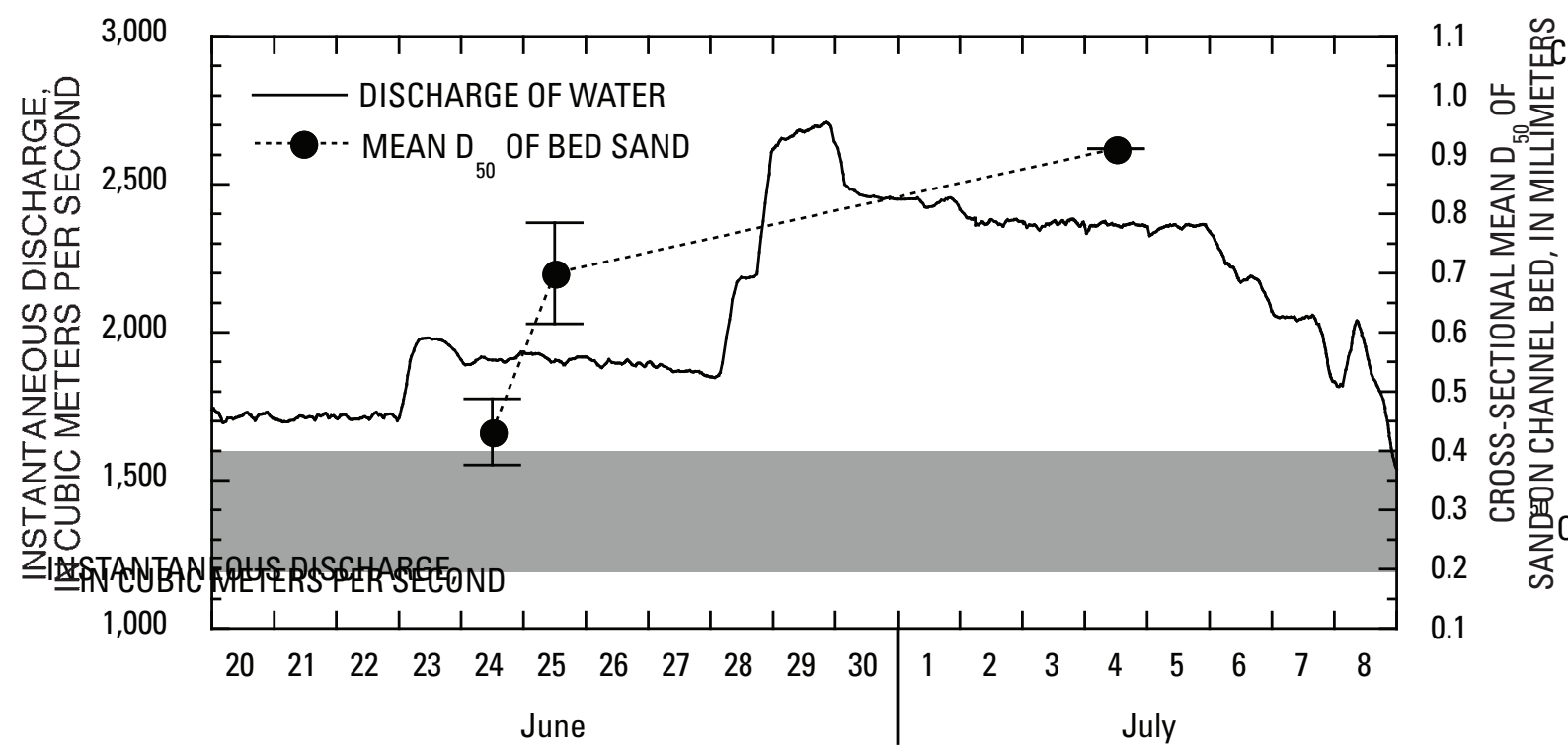

1983

Figure 4. Graph showing mean of the median grain sizes $\left(D_{50}\right)$ of the channel-bed sand over the central two-thirds of the cross section at the Grand Canyon gage in June-July 1983, during the postdam flood of record. Gray-shaded region shows the full predam range in the median grain size of the bed sand at the Grand Canyon gage. Error bars are one standard error. Data are from Garrett and others (1993).

$$
\beta=\frac{D_{b}}{D_{b m}},
$$

where

$D_{b} \quad$ is the median grain diameter of the bed sand at an instance in time, and

$D_{b m} \quad$ is the average of $D_{b}$ over a specified time interval at the same location.

For broad and narrow bed-sand grain-size distributions and cases with and without dunes on the bed, Rubin and Topping (2001) found that

$$
\beta=\left(\frac{C}{C_{m}}\right)^{-0.1}\left(\frac{D_{s}}{D_{s m}}\right)^{0.2}
$$

where

$$
\begin{gathered}
C \quad \begin{array}{c}
\text { is the concentration of sand in suspension at } \\
\text { an instance in time, }
\end{array} \\
C_{m} \quad \begin{array}{c}
\text { is the average of } C \text { over a specified time } \\
\text { interval at the same location, }
\end{array} \\
D_{s} \quad \text { is the median grain diameter of sand in } \\
\text { suspension at an instance in time, and } \\
D_{s m} \quad \begin{array}{c}
\text { is the average of } D_{s} \text { over a specified time } \\
\text { interval at the same location. }
\end{array}
\end{gathered}
$$

This result was computed using suspended-sediment theory reviewed by McLean (1992).

Recently, Rubin and Topping (in press) found that the second exponent in equation (2) was incorrect owing to a typographical error in the column headings in table 1 in Rubin and Topping (2001). In table 1, the headings for the sixth and ninth columns were inadvertently interchanged. The heading for the sixth column in table 1 in Rubin and Topping (2001) should have been $J /(J M-K L)$, instead of the incorrect $M /(J M-K L)$, and the heading for the ninth column in this table should have been $M /(J M-K L)$, instead of the incorrect $J /(J M-K L)$. This undetected typographical error resulted in the second exponent in equation (2) being set equal to 0.2 , when, to one significant digit, it should have been set equal to 1 . This error adversely affected the $\beta$ analyses in Topping and others (2005) and somewhat weakened the conclusions of Topping and others (2005); hence, the $\beta$ analyses of Topping and others (2005) are recomputed herein using the correct value of 1 for the second exponent in equation (2). The correct version of equation (2) used herein is, therefore,

$$
\beta=\left(\frac{C}{C_{m}}\right)^{-0.1}\left(\frac{D_{s}}{D_{s m}}\right)
$$


When the sand on the channel bed and eddy sandbars is not armored by coarser sediment, changes in $\beta$ at a given location may correlate with changes in the volume of sand stored in the reach upstream. In this case, reductions in $\beta$ indicate fining of the channel-bed and eddy-sandbar surfaces interacting with the flow upstream and suggest an increase in the amount of sand in storage upstream. Conversely, increases in $\beta$ indicate winnowing (that is, coarsening) of the inundated upstream sand deposits and suggest an overall decrease in the amount of sand in storage upstream. In the case where sand on the channel bed or eddy sandbars might be armored or inversely graded, however, changes in $\beta$ may be inversely correlated with the overall sand budget. If the bed is armored or inversely graded, erosion will expose finer sand underneath the surface and cause $\beta$ to decrease, even though the amount of sand in storage also has decreased.

To determine the relative changes in sand grain size on the riverbed in Marble and upper Grand Canyons, $\beta$ was computed for all of the 1983-2000 suspended-sand data from the Lower Marble Canyon and Grand Canyon gages (fig. 5). Analysis of variance indicates that the negative trends in $\beta$ (indicating fining of the bed sand) at the Lower Marble Canyon and Grand Canyon gages are both significant at the $<1.0$ $\mathrm{x} 10^{-16}$ level. For this and subsequent statistical analyses, it is determined that trends or differences in means are significant when the computed level of significance is $<0.05$. The negative trends in $\beta$ at the two gaging stations are, therefore, significant. Segregation of the $\beta$ time series at the two gaging stations into two parts, 1983-86 (that is, the period following the 1983 flood) and 1991-2000, and analysis of these two parts using a Student's t-test comparing the means of two groups with unequal variance yields identical results.

For this and subsequent t-tests, the Student's t-test comparing the means of two groups with equal variance is used when an F-test indicates that the variances of the two groups cannot be determined to be different at the 0.05 level, and the Student's t-test comparing the means of two groups with unequal variance is used when an F-test indicates that the variances of the two groups are different at the 0.05 level. The only difference between these two tests is in the degrees of freedom. The t-test comparing two groups with unequal variance has many fewer degrees of freedom than the t-test comparing two groups of equal variance. At both the Lower Marble Canyon and Grand Canyon gages, the 1983-86 $\beta$-computed bed sand was coarser than the 1991-2000 bed sand at the $<1.0 \times 10^{-16}$ level of significance. Therefore, the next step in this study was to determine which bed environment, the sand on the channel bed or the sand on the bed in the eddies, was most responsible for the fining of the bed sand indicated by the negative trend in $\beta$.

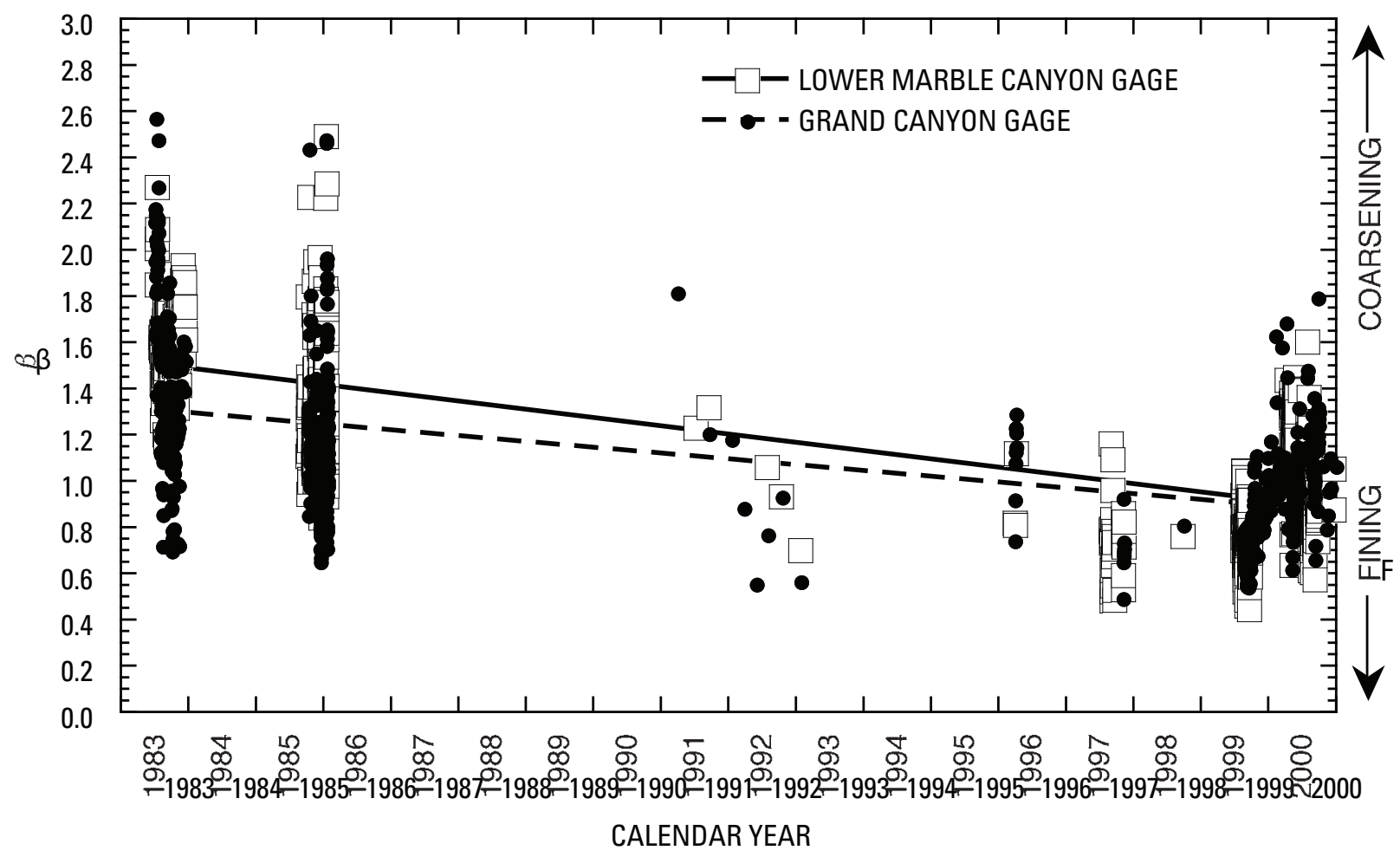

Figure 5. Graph showing $\beta$ time series computed from all 1983-2000 suspended-sand data collected at the Lower Marble Canyon and Grand Canyon gages. The solid line is the linear regression through $\beta$ at the Lower Marble Canyon gage, and the dashed line is the linear regression through $\beta$ at the Grand Canyon gage. Both of these negative (that is, fining) trends are significant. 


\section{Methods}

\section{B-Inferred Changes in the Surface Grain Size of Bed Sand as a Function of Elevation}

To determine the relative changes in sand grain size on the bed of the channel and eddies in three elevation zones in Marble and upper Grand Canyons, $\beta$ was computed for all of the 1983-2000 suspended-sand data from the Lower Marble
Canyon and Grand Canyon gages and segregated into three discharge intervals (fig. 6). These discharge intervals were (1) flows $<250 \mathrm{~m}^{3} / \mathrm{s}$, (2) flows from 250 to $700 \mathrm{~m}^{3} / \mathrm{s}$, and (3) flows $>700 \mathrm{~m}^{3} / \mathrm{s}$. These discharge intervals were chosen on the basis of river morphology and to ensure that sufficient suspendedsand data could be analyzed over the entire study period in each interval. During the study period, flows in the lowest discharge interval $\left(<250 \mathrm{~m}^{3} / \mathrm{s}\right)$ occurred 6 percent of the time, flows in the middle discharge interval $\left(250-700 \mathrm{~m}^{3} / \mathrm{s}\right)$ occurred 65 percent of the time, and flows in the highest discharge interval $\left(>700 \mathrm{~m}^{3} / \mathrm{s}\right)$ occurred 29 percent of the time (though
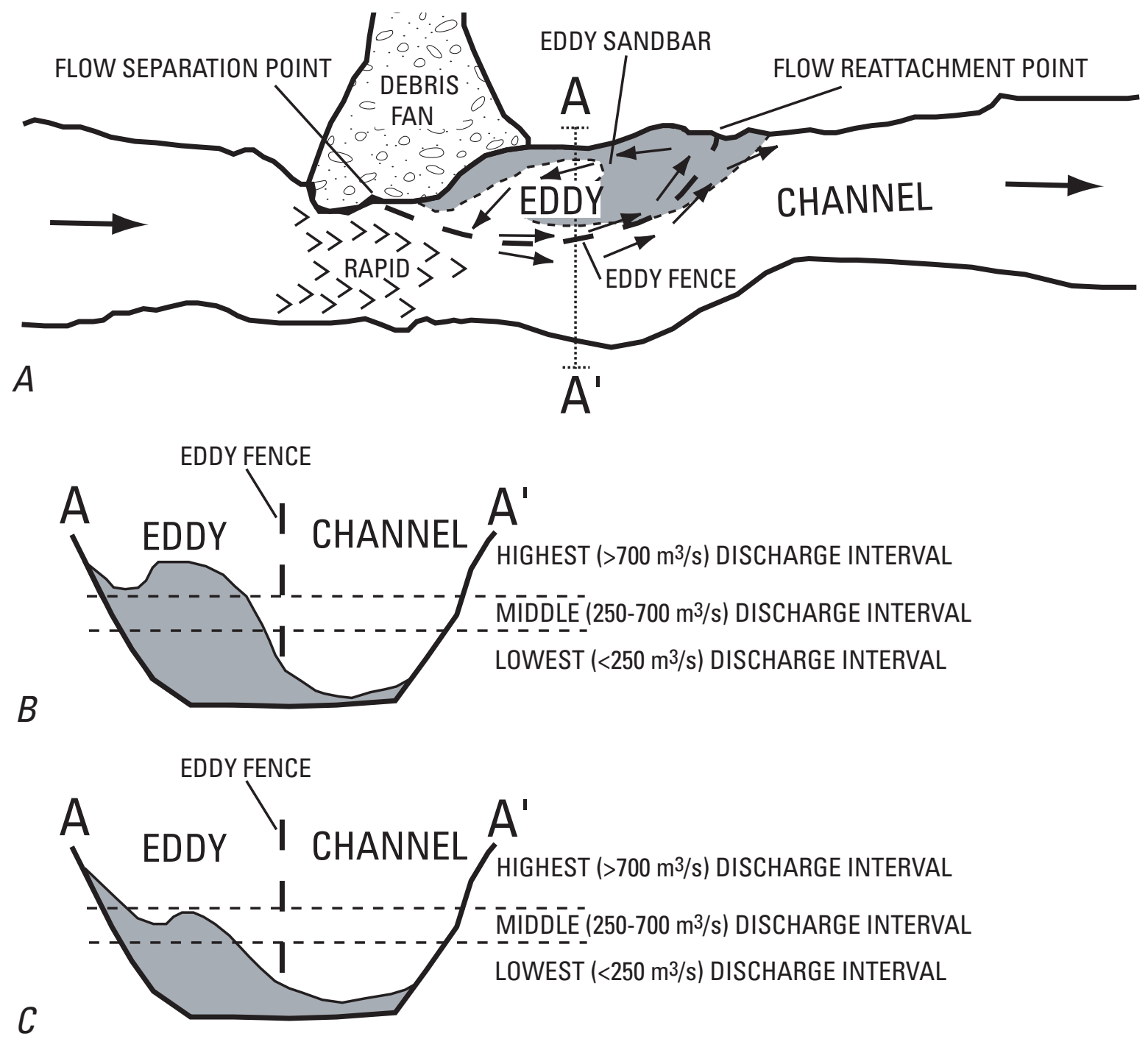

Figure 6. A, Diagram showing a typical fan-eddy complex in Marble and upper Grand Canyons indicating the relative positions of channel and eddy environments. Arrows indicate direction of flow. Modified after Schmidt (1990). B, Cross section through A- $A^{\prime}$ in $A$ showing the approximate elevations of the three discharge intervals used in the $\beta$ analysis immediately after a high dam release (for example, the 1983 flood or 1996 controlled flood). C, Cross section through A-A' in $A$ showing the approximate elevations of the three discharge intervals used in the $\beta$ analysis after subsequent powerplant releases have partially eroded the sandbar. 
mostly during the early part of the study period). By using this approach, changes in $\beta$ over time in the lowest discharge interval could be related to changes in the grain size of the sand on the channel bed and on the lowest elevation part of the eddy-sandbar surfaces. Changes in $\beta$ in the middle discharge interval could be related to a combination of the changes in the sand grain size on the low-elevation part of the bed, plus changes in the sand grain size on the surface of the eddy sandbars within the range of normal powerplant discharges. Similarly, changes in $\beta$ in the highest discharge interval could be related to a combination of the changes in the sand grain size on the low- and mid-elevation parts of the bed, plus changes in the sand grain size on the surface of the eddy sandbars that are inundated only by the highest powerplant releases and in discharges that exceed powerplant capacity $\left(890 \mathrm{~m}^{3} / \mathrm{s}\right)$ at Glen Canyon Dam.

\section{Changes in Sand Grain Size on the Channel Bed and on Eddy-Sandbar Surfaces as Determined From Direct Observations}

Changes in sand grain size on the channel bed were evaluated by using two independent datasets: cross-sectionally averaged datasets collected using USGS BM-54 samplers under the cableways at the Lower Marble Canyon and Grand Canyon gages between 1983 and 2000 (fig. 1), and pipe-dredge datasets collected in the center of the channel at various locations in Marble and upper Grand Canyons on river trips in September 1984, November 1997, March 1998, September 1998, May 1999, September 1999, and May 2000. Each BM-54 measurement consists of a cross-sectional average of the grain size of the bed sand sampled at two or more locations across the channel. These data provide a robust measure of how the sand grain size on the channel bed evolved over time at two locations, the cableways at the Lower Marble Canyon and Grand Canyon gages. The pipe-dredge data, though they contain fewer observations at fewer times than the BM-54 data, have the advantage of providing a more complete spatial measure of the changes in the sand grain size on the channel bed between the Lees Ferry and Grand Canyon gages.

Pipe-dredge samples collected during river trips in September 1984, September 1998, May 1999, September 1999, and May 2000 were used to evaluate changes in the sand grain size on the lowest elevation part of the eddy sandbars. Pipedredge data were collected in the centers of the same 11 eddies in Marble Canyon in September 1998, May 1999, September 1999, and May 2000. During the September 1984 trip, only one eddy was sampled in the study area. The only eddy in

Table 1. Dates, locations, numbers of samples, and sources of data for sampled eddy-sandbar surfaces in Marble and upper Grand Canyons, Ariz.

\begin{tabular}{|c|c|c|c|}
\hline Sampling date & River-mile locations of sampled sandbar surfaces & Source of data & $\begin{array}{l}\text { Number of } \\
\text { samples }\end{array}$ \\
\hline $\begin{array}{l}7-24-1982 \text { to } \\
8-11-1982\end{array}$ & $8,20,22,29.3,43,53,68,76$ & Beus and others (1983) & 8 \\
\hline $\begin{array}{l}7-29-1983 \text { to } \\
8-7-1983\end{array}$ & $\begin{array}{l}8,20,29.3,34.8,43,53,59,61.5,65.5,72.2,75.5 \\
81.3\end{array}$ & Lojko and others (1984) & 32 \\
\hline July-August 1985 & $8,20,29.3,34.7,53,75.5$ & Lojko (1987) & 7 \\
\hline July-August 1986 & $8,20,29.3,34.7,53,75.5,81.3$ & Lojko (1987) & 8 \\
\hline July-August 1991 & 43 & McKay (1991) & 6 \\
\hline April 1996 & $48,63,69.5$ & Rubin and others (1998) & 3 \\
\hline $\begin{array}{l}11-7-1997 \text { to } \\
11-14-1997\end{array}$ & $8,22,30.5,43,47,55.5,62.6,68,81.3$ & Topping and others (2000b) & 12 \\
\hline $5-12-2000$ & $8.8,21.8,30.5$ & $\begin{array}{l}\text { Topping and Rubin at } \\
\text { http://www.gcmrc.gov }\end{array}$ & 3 \\
\hline $\begin{array}{l}8-19-2000 \text { to } \\
8-26-2000\end{array}$ & $\begin{array}{l}1,29.3 .29 .9,30.1,43,43.3,43.4,44.4,59.9,60.2 \\
\quad 63.3\end{array}$ & $\begin{array}{l}\text { Topping and Rubin at } \\
\text { http://www.gcmrc.gov }\end{array}$ & 13 \\
\hline $\begin{array}{l}9-8-2000 \text { to } \\
9-16-2000\end{array}$ & $1,29.3,43,44,60,60.3,62.5,63,65$ & $\begin{array}{l}\text { Topping and Rubin at } \\
\text { http://www.gcmrc.gov }\end{array}$ & 17 \\
\hline
\end{tabular}


which data were collected in each of the five trips between 1984 and 2000 was the eddy on the left side of the river at RM 60.5 , herein referred to as the "RM 60.5 eddy."

Changes in the surface grain size of the sand on the midand high-elevation parts of the eddy sandbars between 1982 and 2000 were evaluated by using grain-size data that we collected on river trips in 1996, 1997, and 2000, and by using the eddy-sandbar surface grain-size data of Beus and others (1983), Lojko and others (1984), Lojko (1985, 1987), McKay (1991), and McCutcheon (1992). The dates, locations, and numbers of samples used from each dataset are shown in table 1 . To be sure that the samples included in this analysis were from sandbar surfaces that had recently interacted with flow in the river, samples were used that were collected at elevations that had been inundated by dam operations in the months preceding each sampling trip.

Samples collected from four trenches excavated through 1983 flood deposits were used to help evaluate the changes in the surface grain size of eddy sandbars during the course of the 1983 flood. The deposits from this flood form a bench that typically rises 1 to $2 \mathrm{~m}$ above the bench created by the more recent 1996 controlled flood.

\section{Results and Discussion}

\section{$\beta$-Inferred Changes in the Surface Grain Size of Bed Sand as a Function of Elevation}

Analyses of the discharge-binned $\beta$ time series indicate that the greatest universal fining of the bed sand between 1983 and 2000 occurred at higher elevations (fig. 7). The average significant decrease in $\beta$ among the Lower Marble Canyon and Grand Canyon gages was 30 percent in the lowest discharge interval, 34 percent in the middle discharge interval, and 51 percent in the highest discharge interval. Therefore, the surfaces of the eddy sandbars at higher elevations probably fined to a greater degree than did the sand on the bed of the channel, or on the surface of the lowest elevation part of the eddy sandbars.

In the lowest discharge interval $\left(<250 \mathrm{~m}^{3} / \mathrm{s}\right), \beta$ at the Lower Marble Canyon gage decreased by about 37 percent and $\beta$ at the Grand Canyon gage decreased by about 22 percent between 1985 and 2000 (fig. 7A). Analysis of variance indicates that the negative trends in low-discharge $\beta$ (indicating fining of the bed sand) at the Lower Marble Canyon and Grand Canyon gages are significant at the $<1.0 \times 10^{-16}$ and 0.0031 levels, respectively. Segregation of the $\beta$ time series at the Lower Marble Canyon and Grand Canyon gages into two parts, 1985-86 and 1991-2000, and analysis of these two parts using a Student's t-test yields similar results. Based on the results of F-tests, t-tests comparing the means of two groups with unequal variance were conducted on both the Lower Marble Canyon gage and Grand Canyon gage data. At the
Lower Marble Canyon gage, low-discharge $\beta$ was greater (that is, coarser) in 1985-86 than it was in 1991-2000 at the $2.1 \mathrm{x}$ $10^{-13}$ level of significance; at the Grand Canyon gage, lowdischarge $\beta$ was greater in $1985-86$ than it was in 1991-2000 at the 0.031 level of significance. The average significant fining in the low-elevation bed sand was therefore about 30 percent, based on the reductions in low-discharge $\beta$ at the two gaging stations.

In the middle discharge interval $\left(250-700 \mathrm{~m}^{3} / \mathrm{s}\right), \beta$ at the Lower Marble Canyon gage decreased by about 38 percent, and $\beta$ at the Grand Canyon gage decreased by about 29 percent between 1983 and 2000 (fig. 7B). Analysis of variance indicates that the negative trends in mid-discharge $\beta$ at the Lower Marble Canyon and Grand Canyon gages are both significant at the $<1.0 \times 10^{-16}$ level. Segregation of the $\beta$ time series at the two gaging stations into two parts, 1983-86 and 1991-2000, and analysis of these two parts using a Student's t-test yields identical results. Based on the results of F-tests, t-tests comparing the means of two groups with unequal variance were conducted on both the Lower Marble Canyon gage and Grand Canyon gage data. At both the Lower Marble Canyon gage and Grand Canyon gage, mid-discharge $\beta$ was greater in 1983-86 than it was in 1991-2000 at the $<1.0 \mathrm{x}$ $10^{-16}$ level of significance. The average significant fining of the combined low- and mid-elevation bed sand was, therefore, about 34 percent, based on the reductions in mid-discharge $\beta$ at the two gaging stations.

In the highest discharge interval $\left(>700 \mathrm{~m}^{3} / \mathrm{s}\right), \beta$ at the Lower Marble Canyon gage decreased by about 50 percent, and $\beta$ at the Grand Canyon gage decreased by about 52 percent between 1983 and 2000 (fig. 7C). Analysis of variance indicates that the negative trend in high-discharge $\beta$ at the Lower Marble Canyon gage is significant at the $<1.0 \times 10^{-16}$ level, and the negative trend in high-discharge $\beta$ at the Grand Canyon gage is significant at the $2.7 \times 10^{-13}$ level. Segregation of the $\beta$ time series at the two gaging stations into two parts, 1983 and 1996-2000, and analysis of these two parts using a Student's t-test yields similar results. Based on the results of F-tests, a t-test comparing the means of two groups with equal variance was conducted on the Lower Marble Canyon gage data, and a t-test comparing the means of two groups with unequal variance was conducted on the Grand Canyon gage data. At the Lower Marble Canyon gage, high-discharge $\beta$ was greater in 1983 than it was in $1996-2000$ at the $<1.0 \mathrm{x}$ $10^{-16}$ level of significance; at the Grand Canyon gage, highdischarge $\beta$ was greater in 1983 than it was in 1996-2000 at the $6.0 \times 10^{-15}$ level of significance. The average significant fining in the combined low-, mid-, and high-elevation bed sand was, therefore, about 51 percent, based on the large reductions in high-discharge $\beta$ at the two gaging stations.

In addition to the results above, which indicate that (1) fining of the sediment on the surface of the bed occurred at all elevations between the late 1980s and the early 1990s, and (2) this fining was greatest at the higher elevations, the $\beta$ analyses at the Lower Marble Canyon and Grand Canyon gages also indicate that a fundamental change in the grain-size archi- 

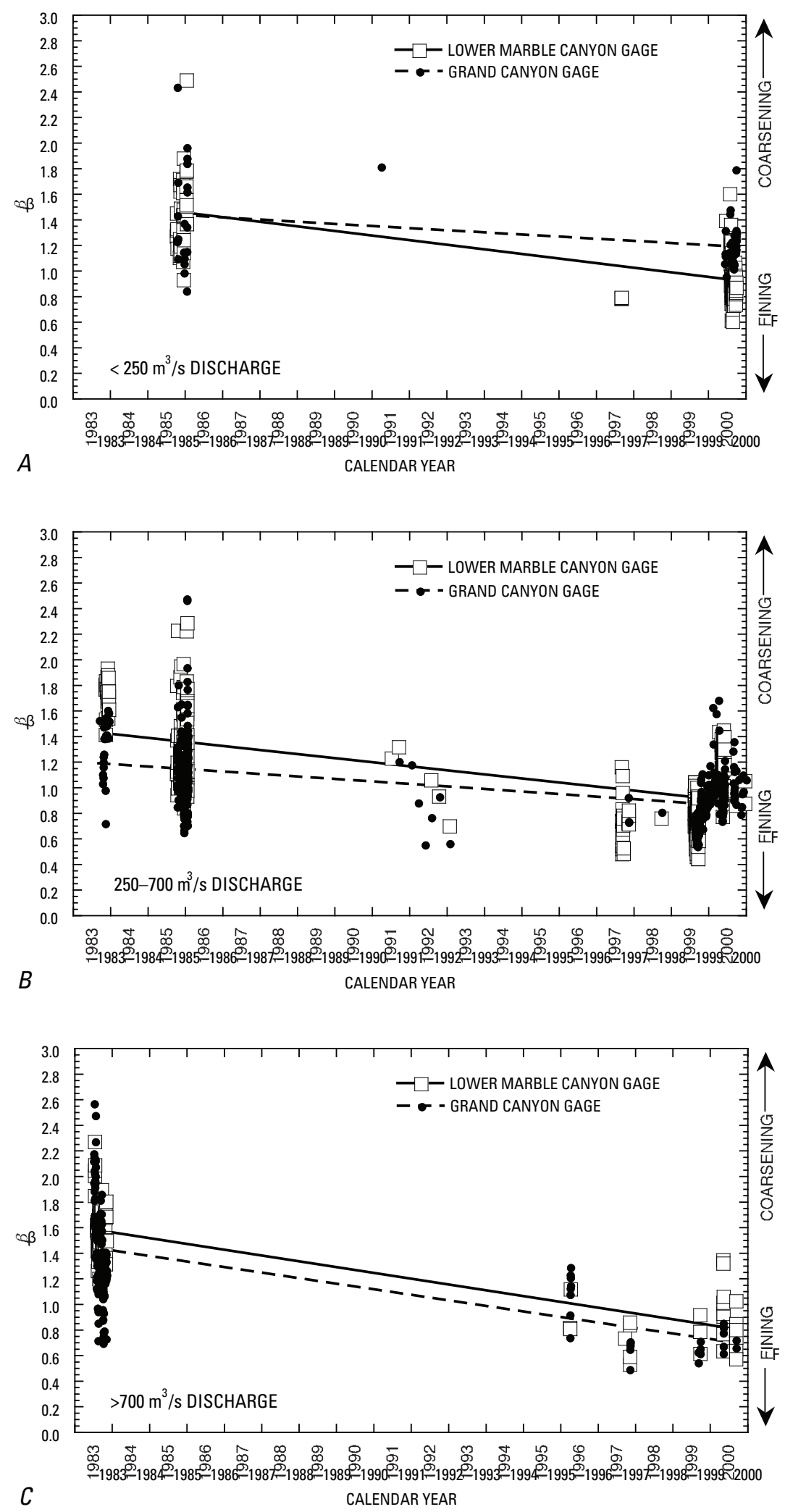

Figure 7. Graphs showing 1983-2000 $\beta$ time series from figure 5 segregated into three discharge intervals. Solid lines are the linear regressions through $\beta$ at the Lower Marble Canyon gage; dashed lines are the linear regressions through $\beta$ at the Grand Canyon gage. The negative (that is, fining) trends at both gaging stations are significant in each of these three discharge intervals. $A$, $\beta$ time series for the lowest discharge interval $\left(<250 \mathrm{~m}^{3} / \mathrm{s}\right) . B, \beta$ time series for the middle discharge interval $\left(250-700 \mathrm{~m}^{3} / \mathrm{s}\right) . C, \beta$ time series for the highest discharge interval $\left(>700 \mathrm{~m}^{3} / \mathrm{s}\right)$. 
tecture of the surfaces of the channel bed and eddy sandbars of the Colorado River in Marble and upper Grand Canyons occurred between 1986 and 1991 (fig. 8). The $\beta$ analyses at these two gaging stations indicate that, during 1991-2000, the grain-size architecture of the Colorado River in Marble and upper Grand Canyons was similar to that observed in other rivers, with progressively finer sand present on the surface of the bed at higher elevations in the eddy sandbars. As the discharge increases in a river with this "normal" grain-size architecture, more finer sand at higher elevations on the bed is inundated by the flow and is, therefore, available to go into suspension. Rubin and Topping (2001) reported this type of behavior for the Colorado River (pre- and postdam) and two alluvial rivers (the Paria and Mississippi Rivers). During the high-flow dominated period from the 1983 flood through 1986, however, $\beta$ increased with increasing discharge at both gaging stations. This type of behavior in $\beta$ can only occur in a river if increases in discharge result in coarser sand on the bed being available to go into suspension. During the 1983-86 period, this behavior probably resulted from a combination of (1) an extreme degree of winnowing of the channel bed during individual floods, as shown in figure 4, and (2) an "inverse" grain-size architecture, with much coarser sand present on the higher elevation surfaces of the eddy sandbars than is typical (for example, during 1991-2000). Direct field evidence for this second process is provided in figure 8 .

\section{Changes in Sand Grain Size on the Channel Bed}

Despite the short-term large changes in the sand grain size on the channel bed described in the introduction, the sand grain size on the channel bed has either not changed, or has coarsened by about 10 to 20 percent during the 17 years following the 1983 flood. This result is in disagreement with the results from the low-discharge $\beta$ analyses at the Lower Marble Canyon and Grand Canyon gages that showed significant fining in the grain size of the low-elevation bed sand upstream from both gaging stations. Thus, the average 30 percent decrease observed among low-discharge $\beta$ at the two gaging stations between 1983 and 2000 was not due to fining of the sand on the channel bed, but was more likely due to fining of the sand on the surface of the lowest elevation part of the eddy sandbars.

Analyses of variance of the cross-sectionally averaged BM-54 datasets from the Lower Marble Canyon and Grand Canyon gages indicate that the sand on the channel bed at both of these locations coarsened slightly (by 10 to 20 percent) from 1983 through 2000 (fig. 9). The large variability in channel-bed grain size at each gaging station within each year results from the short-term changes in channel-bed grain size described in the Introduction, with fining of the bed during periods of upstream tributary resupply of finer sand and winnowing of the bed either after cessation of upstream tributary activity, or during periods of high dam releases. During 1983-2000, the cross-sectional mean of the median grain size of the sand on the channel bed at the Lower Marble Canyon gage coarsened from about 0.36 to $0.40 \mathrm{~mm}$, and the cross-sectional mean of the median grain size of the sand on the channel bed at the Grand Canyon gage coarsened from about 0.37 to $0.43 \mathrm{~mm}$. Owing to the large number of observations, these slight coarsening trends are significant at the 0.0073 and $2.4 \times 10^{-7}$ levels, respectively. Segregation of the time series at the two gaging stations into two parts, 1983-86 and 1996-2000, and analysis of these two parts using a Student's t-test comparing the means of two groups with unequal variance yields similar results. The sand on the channel bed at the Marble Canyon gage was coarser in 1996-2000 than it was during 1983-86 at the 0.00011 level of significance, and the sand on the channel bed at the Grand Canyon gage was coarser in 1996-2000 than it was during 1983-86 at the 0.00045 level of significance. Furthermore, although comparable with the coarsest predam value $(0.4 \mathrm{~mm})$, the cross-sectional mean of the median grain size of the channel-bed sand at the Grand Canyon gage during 1983-2000 was 90 percent coarser than the finest predam value $(0.2$ $\mathrm{mm}$ ) and 27 percent coarser than the mean predam value (fig. 9).

Analyses of the seven pipe-dredge datasets show that, despite substantial short-term fining of the channel-bed sand in uppermost Marble Canyon following floods on the Paria River, there is no significant difference between the grain size of the sand on the channel bed measured on each of the river trips from September 1984 through May 2000 (fig. 10). Analysis of variance of the data in figure $10 \mathrm{~A}$ indicates that, at the 0.11 level of significance, variance is minimized when the 1984-2000 pipe-dredge data are treated as a single dataset rather than seven different datasets. In other words, at the 0.11 level of significance, the variance about a single linear regression fit to all of the 1984-2000 data is less than the variance about different linear regressions fit to the data from each of the seven trips. Therefore, because this level of significance is $>0.05$, it cannot be concluded that the 1984-2000 data in figure $10 \mathrm{~A}$ are seven different datasets. Although the longitudinal mean of the median grain size of the channel-bed sand was slightly finer in the late 1990s than it was in September 1984, analysis of variance indicates that the slight fining trends in the longitudinal mean of the median grain sizes of the channel-bed sand in Marble and upper Grand Canyons are not significant (fig. 10B).

Segregation of the data in figure $10 B$ into two parts, 1984 and combined 1997-2000, and analysis of these two parts from Marble and upper Grand Canyons using a Student's t-test yields a slightly different result. In Marble Canyon, analysis using a t-test comparing the means of two groups with equal variance indicates that the longitudinal mean of the median grain sizes of the channel-bed sand in the combined 1997-2000 dataset is slightly finer than it was during the 1984 river trip, at the 0.046 level. Because this level of significance is essentially identical to the 0.05 level set as the threshold for significance in the analyses, this difference may or may not be significant. In any case, 


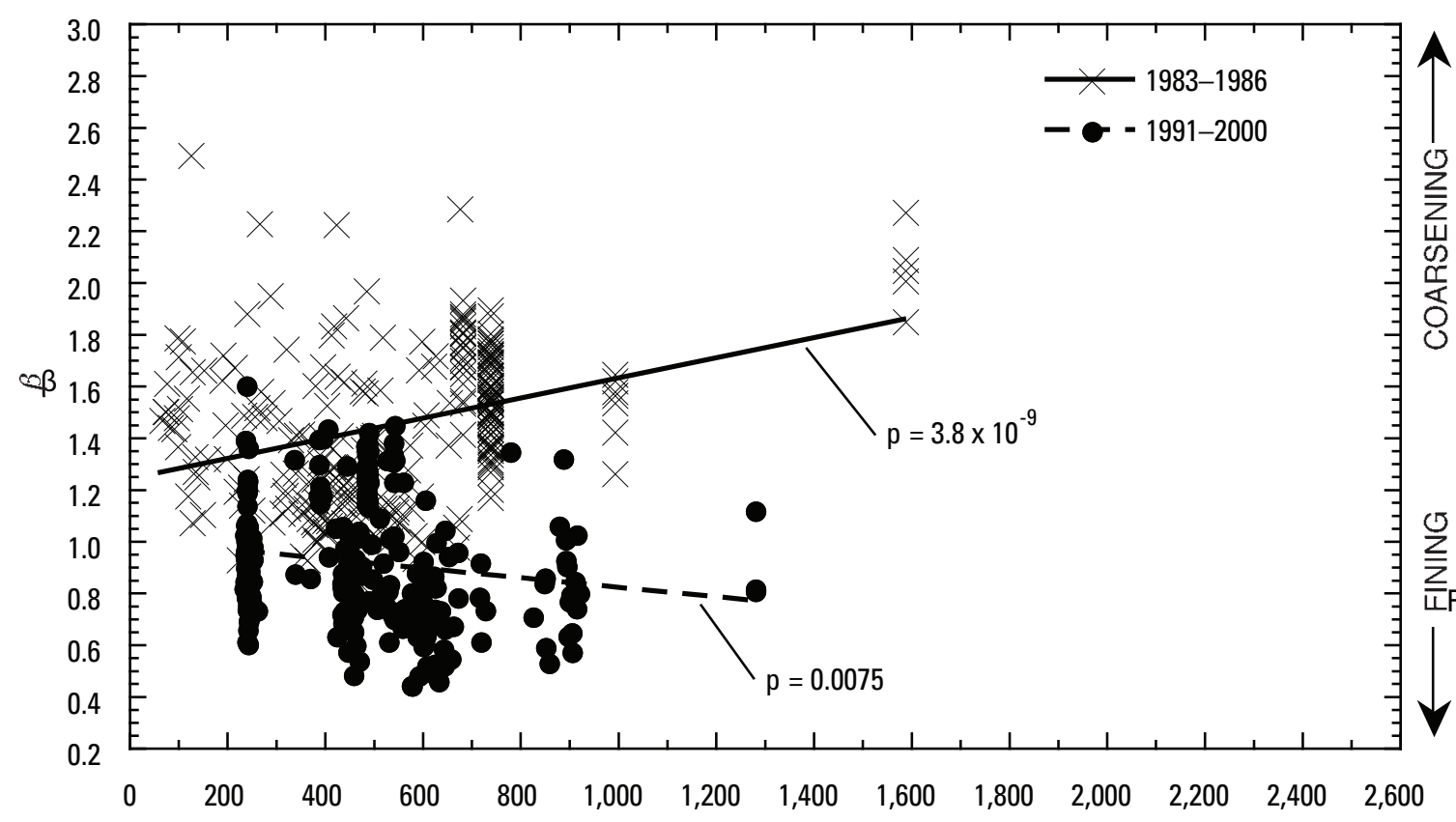

A INSTANTANEOUS DISCHARGE, IN CUBIC METERS PER SECOND

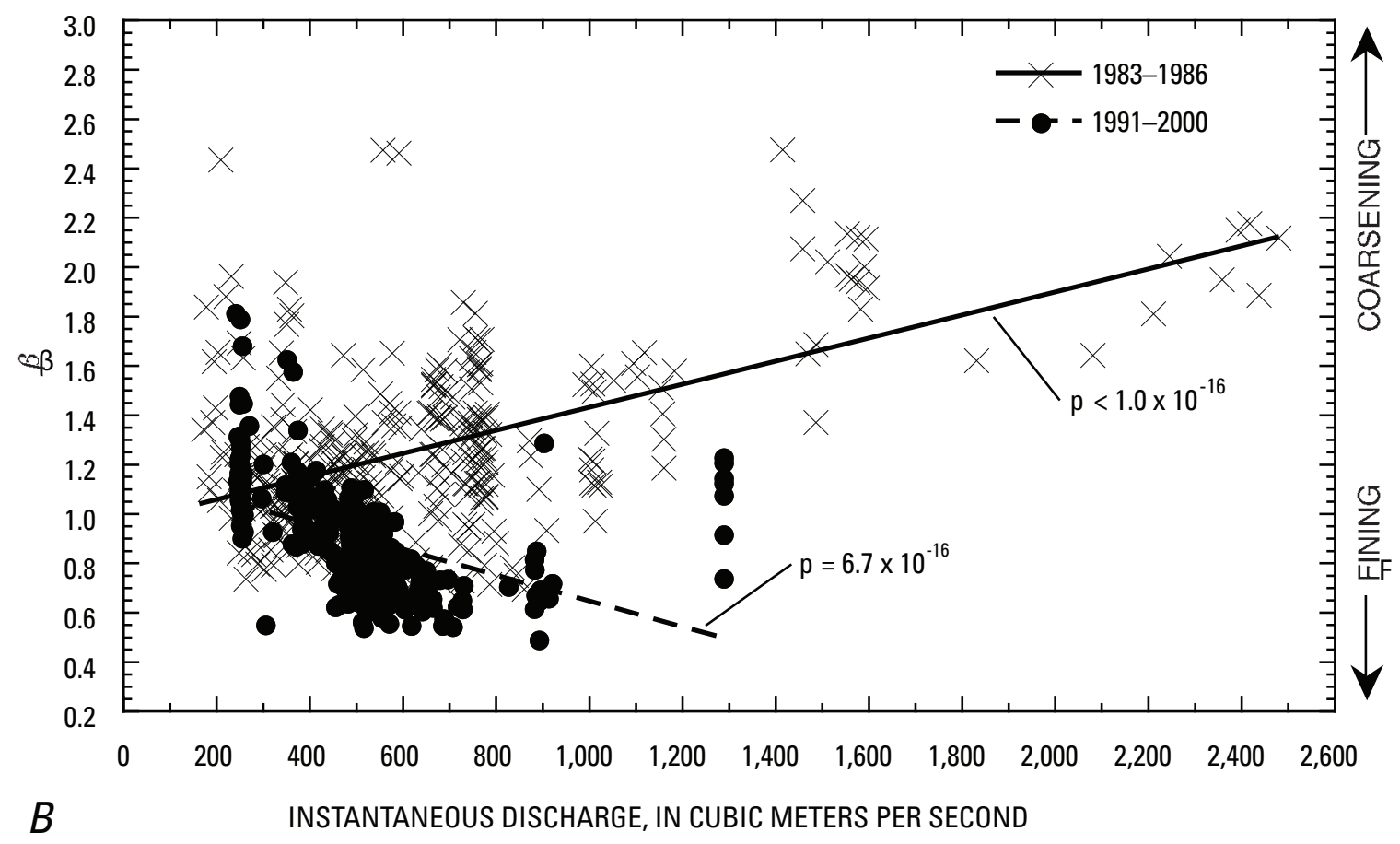

Figure 8. Graphs showing $\beta$ as a function of the discharge of water at $(A)$ the Lower Marble Canyon gage, and $(B)$ the Grand Canyon gage. Solid lines are the linear regressions through the 1983-86 data; dashed lines are the linear regressions through the 1991-2000 data. Levels of significance ( $p$ ) of the trends in $\beta$ as a function of discharge are indicated. 

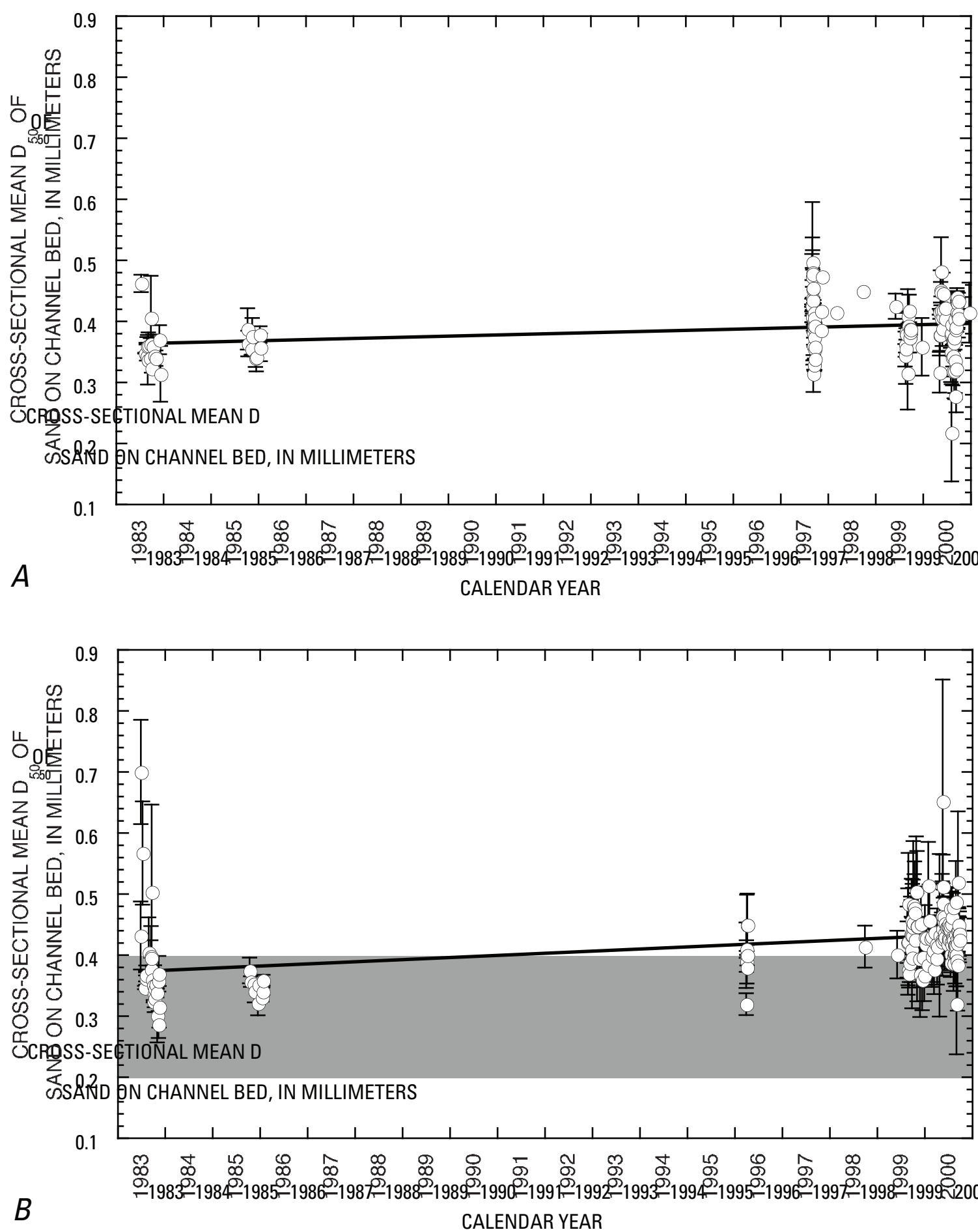

Figure 9. Graphs showing temporal variation in sand grain size on the channel bed at the Lower Marble Canyon and Grand Canyon gages from 1983 through 2000. The cross-sectional mean of the median grain size is computed by averaging the median grain sizes of the sand from two or more samples collected across the central two-thirds of the cross section. Error bars are one standard error. $A$, Cross-sectional mean of the median grain size $\left(D_{50}\right)$ of the sand on the bed at the Lower Marble Canyon gage. Solid line is the linear regression through these data. $B$, Cross-sectional mean of the median grain size $\left(\mathrm{D}_{50}\right)$ of the sand on the bed at the Grand Canyon gage. Gray-shaded region shows the full predam range in the median grain size of the bed sand at this location. Solid line is the linear regression through these data. All data in $A$ and $B$ were collected by using a BM-54 sampler except for the data in September 1998 and May 1999, which were collected by using a pipe dredge. Data are from Garrett and others (1993) and http://www.gcmrc.gov. 

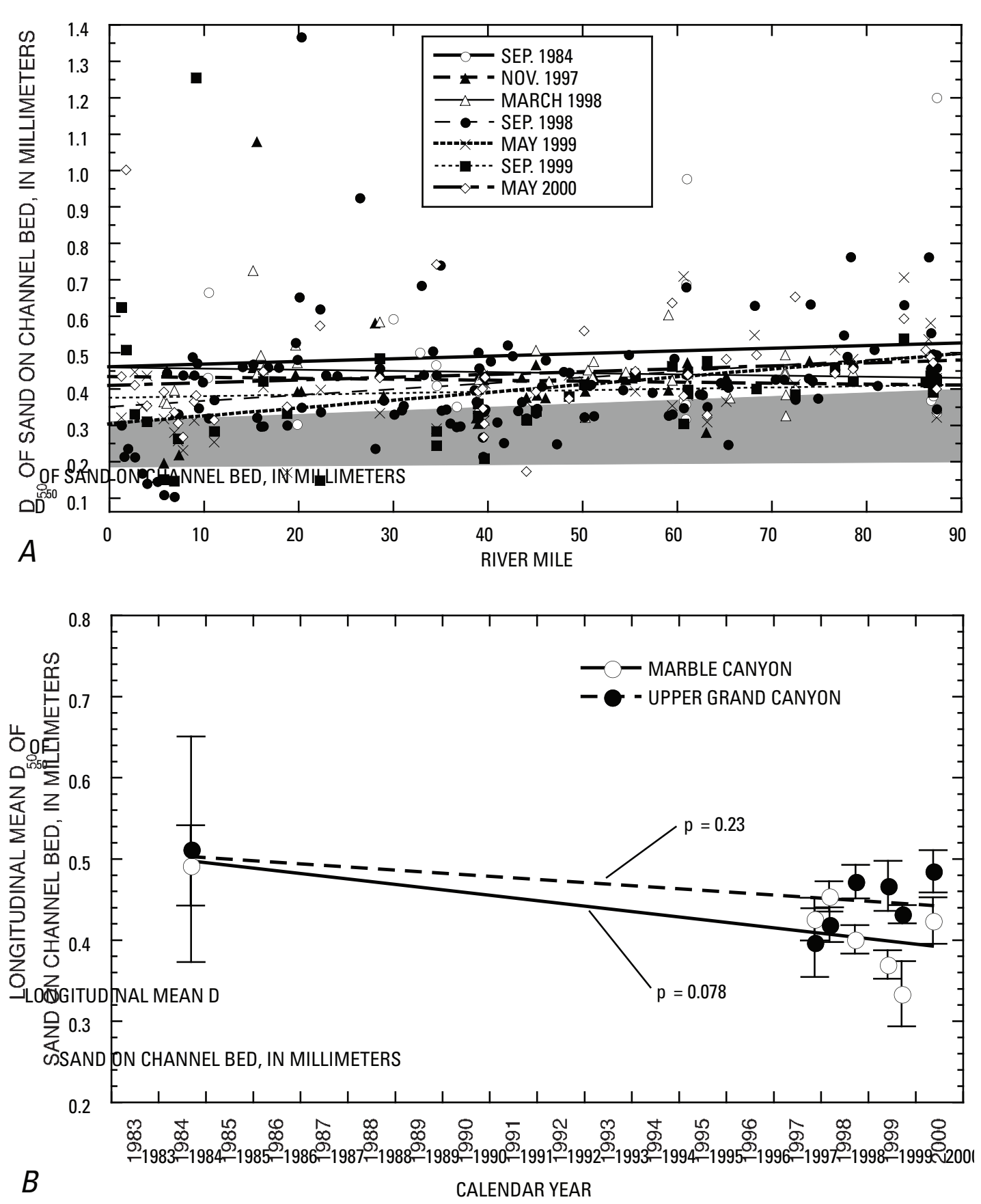

Figure 10. Graphs showing longitudinal and temporal variation in sand grain size on the channel bed between the Lees Ferry and Grand Canyon gages, from 1984 through 2000, determined from pipe-dredge data. $A$, Longitudinal variation in the median grain sizes $\left(D_{50}\right)$ of the channel-bed sand between the Lees Ferry and Grand Canyon gages during seven river trips made between 1984 and 2000. Solid and dashed lines are the linear regressions through the data from each of the river trips. Analysis of variance indicates that the data from the seven trips are not significantly different and that variance is minimized when the 1984-2000 pipe-dredge data are treated as a single dataset. Gray-shaded region shows the predam range in the median grain size of channel-bed sand interpolated between the measurements at the Lees Ferry and Grand Canyon gages. $B$, Temporal variation in the longitudinal mean of the median grain sizes in $A$ for Marble and upper Grand Canyons. Error bars are one standard error. Solid line is the linear regression through the longitudinal mean of the median grain sizes of the channel-bed sand in Marble Canyon, and the dashed line is the linear regression through the longitudinal mean of the median grain sizes of the channel-bed sand in upper Grand Canyon. Levels of significance $(p)$ of the slight fining trends are indicated. At the 0.05 level, no significant trend exists in the longitudinal mean of the median grain sizes of the channel-bed sand between 1984 and 2000. 
the slight difference between the 1984 and combined 1997-2000 Marble Canyon data is likely the result of the short-term fining of the channel bed in September 1999 following large Paria River floods. In upper Grand Canyon, analysis using a t-test comparing the means of two groups with unequal variance indicates that the longitudinal mean of the median grain sizes of the channel-bed sand in the combined 1997-2000 dataset is slightly finer than it was during the 1984 river trip, but at only the 0.71 level (a difference that is not significant).

\section{Changes in the Surface Grain Size of Sand on the Lowest Elevation Part of Eddy Sandbars}

Pre-1997 data from the lowest elevation part of eddy sandbars are extremely sparse, and it is impossible to know, based on direct observations of grain size only, whether any major change in the grain size of sand on the lowest elevation part of eddy sandbars occurred between 1984 and 2000 (fig. 11). Analysis of the data from the one eddy sampled throughout the study period (that is, the RM 60.5 eddy) indicates that the grain size of sand on the lowest elevation part of this eddy sandbar was relatively coarse and of similar size during the September 1984, September 1998, and September 1999 river trips, and was relatively fine and of similar size during the May 1999 and May 2000 river trips (fig. 11B). Finally, despite the observation in figure $11 A$ that sand sampled on the lowest elevation part of eddy sandbars in uppermost Marble Canyon tended to be finer in September after new inputs of sand from the Paria River (as was the case on the channel bed in the previous section), there is no statistically significant difference in the longitudinal mean of the median grain size on the lowest elevation part of the eddy sandbars among the 11 eddies sampled in Marble Canyon between September 1998 and May 2000 (fig. 11B).

\section{Changes in the Surface Grain Size of Sand on the Mid- and High-Elevation Parts of Eddy Sandbars}

Substantial changes in the mean median grain size of the eddy-sandbar surfaces at mid and high elevations occurred in Marble and upper Grand Canyons between August 1982 and September 2000 (fig. 12A). The eddy-sandbar surfaces coarsened during the 1983 flood, remained coarse through 1986, fined between 1986 and 1991, and then remained relatively fine through 2000. The mid- and high-elevation parts of the eddy sandbars are, therefore, the only riverbed environment that tracks with the reductions observed in $\beta$ between 1983 and 2000. In addition, the discharge-binned $\beta$ analyses presented above indicate that the greatest amount of fining over time in the bed sand sampled by the suspended sand occurred at the highest elevations. The grain size of the eddy-sandbar surfaces was thus the most important regulator of sand transport during the study period.

The 1983 flood deposited coarsening-upward flood deposits, causing the surface grain size of the eddy sandbars to coarsen substantially and significantly. Subsequent surface grain-size data collected by Lojko (1985, 1987), McKay (1991), and McCutcheon (1992) indicate that the regularly inundated surfaces on the eddy sandbars remained coarse through at least August 1986, and began fining in the late 1980s and early 1990s. In August 1982, the mean median grain size of the sand on the surface of the eddy sandbars was $0.14 \mathrm{~mm}$ (Beus and others, 1983). This value is within the $0.12-0.19 \mathrm{~mm}$ range of median grain sizes of the sand on the surfaces of eddy sandbars in the mid-1970s reported by Howard and Dolan (1981). Following the 1983 flood, the mean median grain size of sand on the eddy sandbars in Marble and upper Grand Canyons coarsened by a factor of 1.8 to a value of $0.25 \mathrm{~mm}$ (Beus and others, 1983; Lojko and others, 1984). Analysis of the 1982 and 1983 data using a Student's t-test comparing the means of two groups with equal variance indicates that the coarsening of the eddy-sandbar surfaces during the 1983 flood was significant at the $3.3 \times 10^{-7}$ level. An identical degree of average coarsening was observed in four trenches excavated through 1983 flood deposits in Marble and upper Grand Canyons (fig. 12B).

The similarity of the magnitude and direction of the changes in the grain size of the eddy-sandbar surfaces with the observed factor of 2 coarsening of the channel-bed sand at the Grand Canyon gage during the 1983 flood (fig. 4) suggests that the sand supplied to the eddy sandbars during the 1983 flood coarsened through time as the bed of the channel was winnowed. Thus, it is likely that the coarsening of the eddy-sandbar surfaces during the 1983 flood was due to the same processes observed by Rubin and others (1998) and Topping and others (1999) during the 1996 controlled flood, and observed by Topping and others (2000b) during the 2 -day powerplant-capacity release $\left(890-\mathrm{m}^{3} / \mathrm{s}\right)$ in November 1997. Coarsening-upward eddy deposits were also produced during two 4-day powerplant-capacity releases in 2000 (data available from http://www.gcmrc.gov). During all of these high-discharge releases from the dam, the upstream supply of sand decreased, causing the bed to winnow. This coarsening of the channel bed, in turn, caused the sand available to be deposited in eddies to coarsen, resulting in coarsening-upward flood deposits and a general coarsening of the eddy-sandbar surfaces.

Grain-size data collected from eddy-sandbar surfaces during the late 1990s indicate that, after the eddy-sandbar surfaces fined between 1986 and the early 1990s, these surfaces remained relatively fine through 2000. Analysis of the combined 1983-86 and combined 1991-2000 data using a Student's t-test comparing the means of two groups with unequal variance indicates that the fining of the bar surfaces between 1986 and 1991 was significant at the $2.6 \times 10^{-11}$ level. The fining of the bar surfaces in the late 1980s probably was 

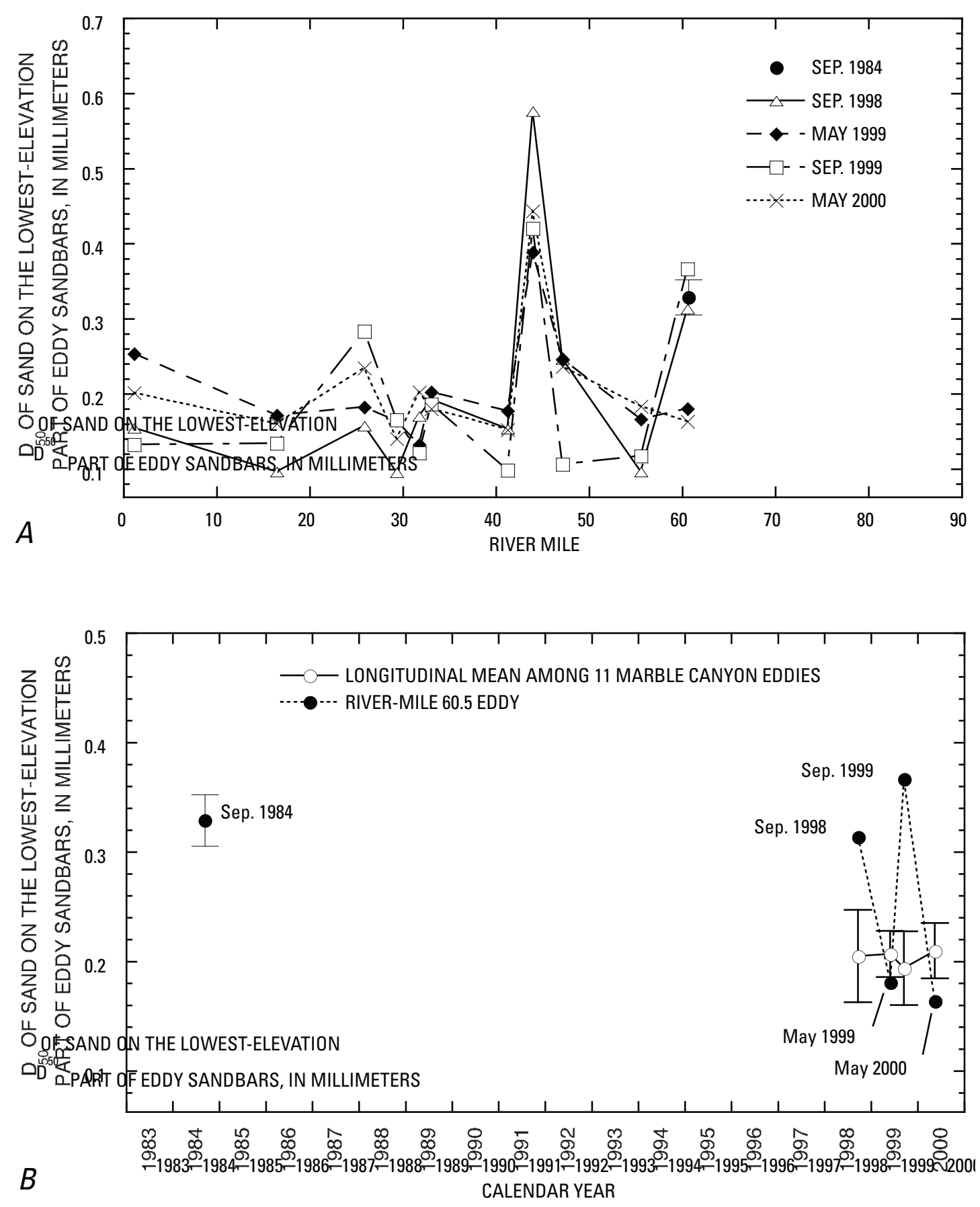

Figure 11. Graphs showing longitudinal and temporal variation in sand grain size on the lowest elevation part of eddy sandbars in Marble Canyon as determined from pipe-dredge data. Error bars are one standard error. $A$, Longitudinal variation in the median grain sizes $\left(D_{50}\right)$ of the sand on the lowest elevation part of the 11 eddy sandbars sampled between 1984 and 2000. Two samples were collected in September 1984 from the sandbar in the RM 60.5 eddy. $B$, Temporal variation in the longitudinal mean of the median grain sizes in $A$, and the median grain size of the sand on the lowest elevation part of the sandbar in the only eddy sampled in 1984 and in 1998-2000, the RM 60.5 eddy. 

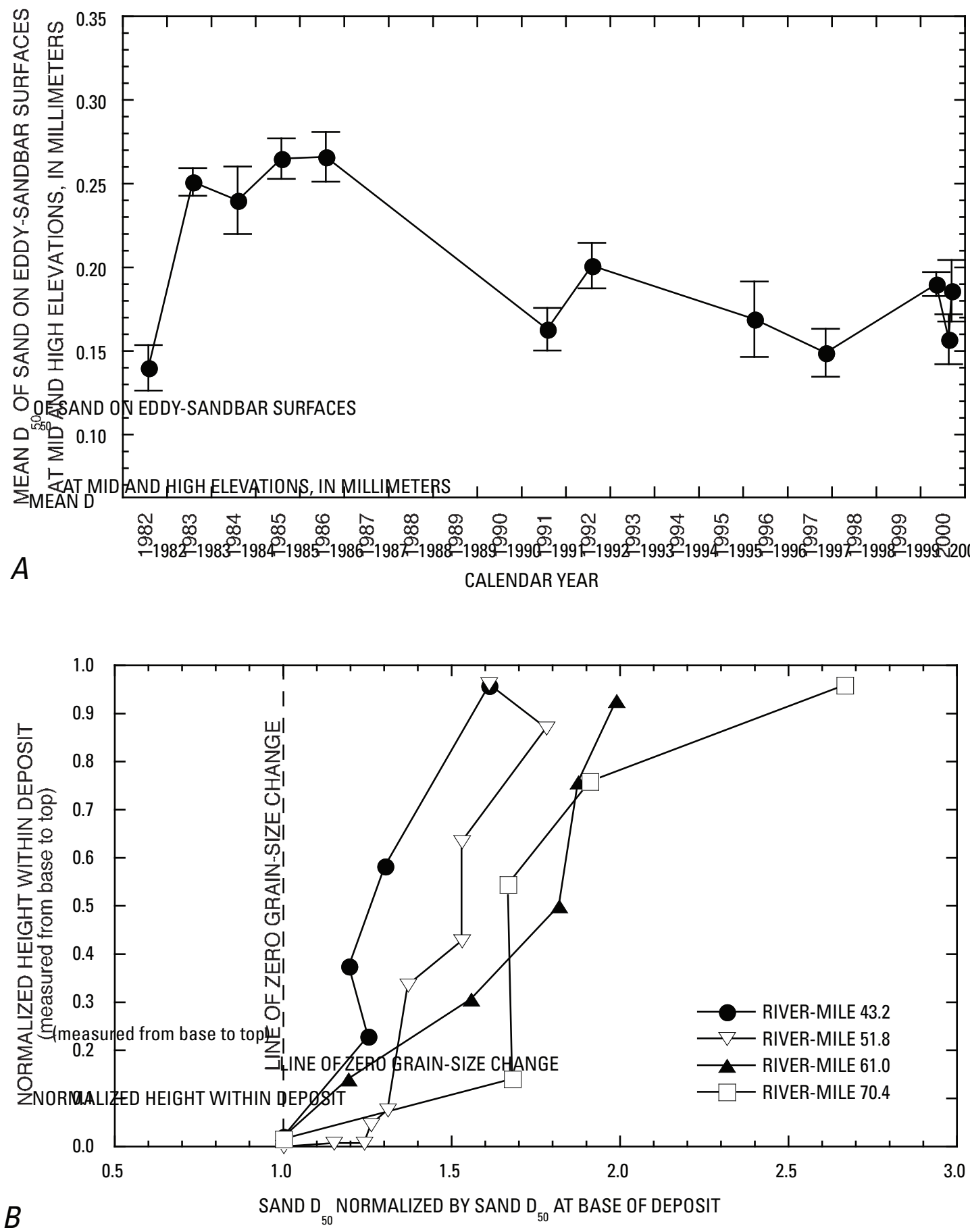

Figure 12. Graphs showing $(A)$ mean of the median grain sizes $\left(D_{50}\right)$ of the sand on eddy-sandbar surfaces at mid and high elevations in Marble and upper Grand Canyons from 1982 through 2000. Error bars are one standard error. $(B)$ Normalized median grain size $\left(D_{50}\right)$ of sand measured vertically through four 1983 flood deposits in Marble and upper Grand Canyons. Median grain sizes at each elevation were normalized by dividing by the median grain size at the base of the deposit. These four deposits coarsened upward by a mean factor of 1.8, in agreement with the observed factor of 1.8 coarsening of the eddy-sandbar surfaces between 1982 and 1983 in $A$. 
due to three different processes: (1) lateral erosion through the coarsening-upward 1983 flood deposits, (2) reworking or addition of a thin layer of finer sand supplied from upstream eddy sandbars and tributaries, and (3) less depletion of the upstream supply of finer sand during the 1996 controlled flood and 1997 and 2000 powerplant-capacity releases, compared to the greater depletion of finer sand during the much larger 1983 flood.

The area of eddy sandbars decreased by gradual lateral erosion from the mid-1980s to just prior to the 1996 controlled flood (Schmidt and others, 2004). Rubin and others (1994) and Barnhardt and others (2001) showed that the basal contact of the 1983 flood deposit generally slopes offshore at a gentle angle in the eddy sandbars, and that the 1983-86 high-flow deposits overlay older pre-1983 deposits. Therefore, as lateral erosion progressed during the late 1980s and early 1990s, the coarser surfaces of the 1983-86 eddy sandbars were gradually removed, exposing the finer sand at progressively greater depths and lateral distances within the 1983 flood deposits (fig. 13). This newly exposed finer sand was then available for downstream transport and could be added to downstream eddy sandbars. Similarly, new finer sand supplied from upstream tributaries and deposited on the eroding 1983-86 eddy-sandbar surfaces caused additional fining of the sandbar surfaces. An example of this last process was the deposition of finer sand on the coarser surfaces of eddy sandbars in Grand Canyon during large floods on the Little Colorado River in 1993, as described by Rubin and others (1994).

Available USGS bed-grain-size data collected during the 1996 controlled flood and during the 1997 and 2000 powerplant-capacity releases indicate that the sand on the bed of the channel never coarsened during these smaller floods to the degree that it did during the 1983 flood. Likewise, available USGS suspended-sand data indicate that, throughout the 1996 controlled flood, suspended-sand concentrations were higher and suspended-sand grain sizes were finer than during the larger 1983 flood. Similarly, USGS suspended-sand data indicate that, throughout the peaks of the much lower 1997 and 2000 powerplant-capacity releases, suspended-sand concentrations were comparable with those measured during the peak of the 1983 flood, and suspended-sand grain sizes were finer than those measured during the peak of the 1983 flood. Thus, although the upstream sand supply decreased during all five high clearwater dam releases, the upstream supply of sand became more depleted during the 1983 flood than during the 1996 controlled flood or the 1997 and 2000 powerplant-capacity releases. Therefore, the sand available to be transported from the channel into eddies at the peak of the 1983 flood was much coarser than that available to be transported into eddies during the 1996, 1997, and 2000 high-discharge releases.

\section{Conclusions}

This study shows that $\beta$ analyses of suspended-sediment data can be used in conjunction with analyses of surfacegrain-size data to deduce which environments in a complicated setting are the most important environments for regulating sediment transport, regardless of whether these environments represent a relatively large or small part of the total environment. In the case of the sand-supply-limited Colorado River in Marble and upper Grand Canyons, the bed environment that is the dominant regulator of sand transport in the river over multiyear timescales, the eddy environment, represents only a small percentage of the total area of the river.

In Marble and upper Grand Canyons, grain-size data indicate that the only environment in which the grain size of the bed sand substantially changed over multiyear timescales was the surface of the eddy sandbars. As the upstream supply of sand became depleted during the 1983 flood, the sand in suspension and on the bed of the channel coarsened. This led to the production of coarsening-upward flood deposits in eddies. As a result of this process, the eddy-sandbar surfaces coarsened by about a factor of 1.8 during the 1983 flood and remained relatively coarse through the high flows of 1984 , 1985, and 1986. Then, as the eddy sandbars eroded, exposing underlying finer sand (and mixing in finer sand supplied from upstream), the eddy-sandbar surfaces fined such that the sandbar surfaces in 1991-2000 were not substantially coarser than they were in either 1982 or the mid-1970s.

$\beta$ analyses at both the Lower Marble Canyon and Grand Canyon gages suggest that the dominant signal in the suspended-sand data collected since 1983 has been the fining of the eddy-sandbar surfaces as the bars eroded between the mid1980s and the early 1990s. This fining in the eddy-sandbar surfaces resulted in a fundamental change in the grain-size architecture of the Colorado River, from inverse to normal. This finding has major implications for sand transport in Marble and upper Grand Canyons. Between 1986 and the early 1990s, the median grain size of the sand on the eddysandbar surfaces decreased by about 30 to 40 percent. Topping and others (2000b, fig. 18) showed that, for a narrow grainsize distribution in deeper water, this magnitude of change in bed grain size corresponds to about a factor of two increase in the concentration of sand in suspension over this surface. For the more general case in shallower water, Rubin and Topping (2001) showed that this effect would be only slightly smaller. Thus, as the eddy-sandbar surfaces became finer, substantially more sand could be carried in suspension over the eddy sandbars. This increase in flux over the eddy-sandbar surfaces as the bar surfaces fined can lead to greater deposi- 


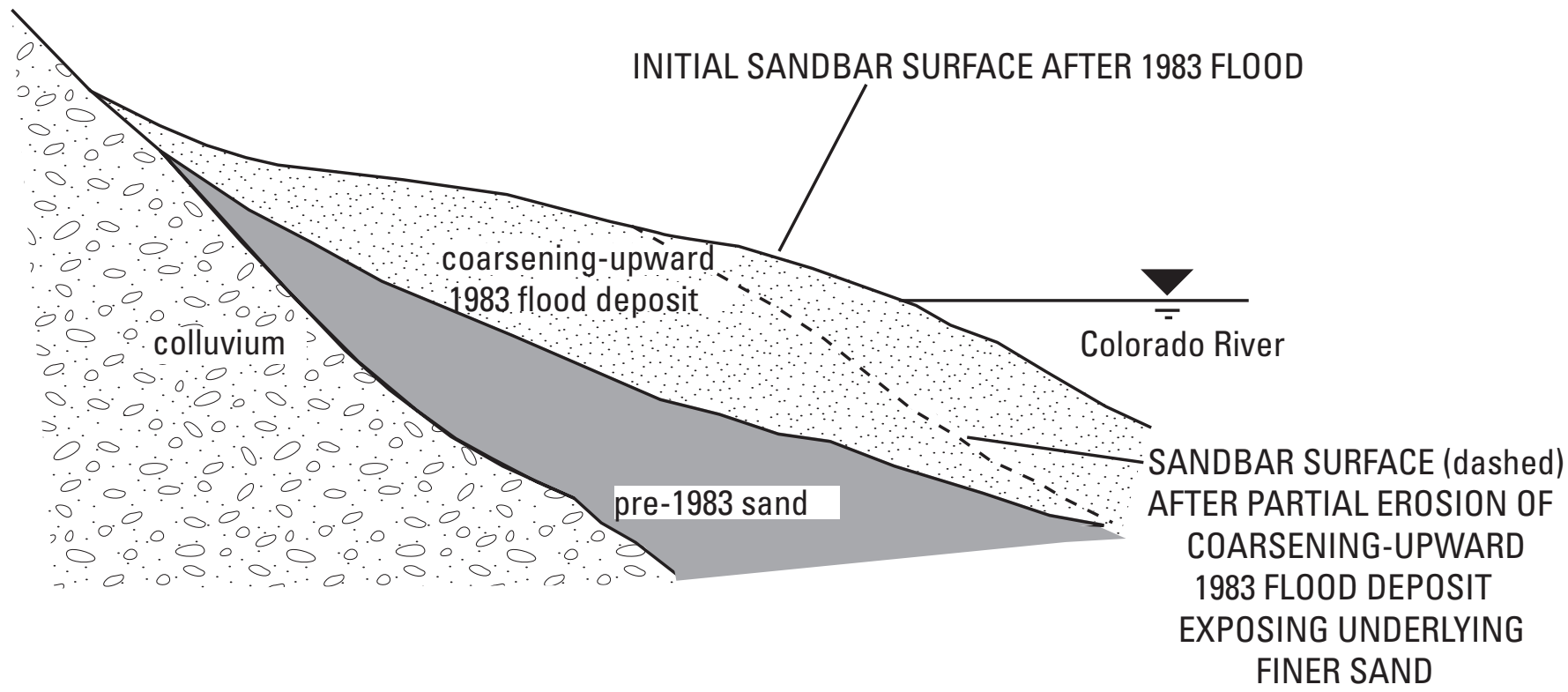

Figure 13. Diagram of an idealized cross section (from Rubin and others (1994) and Barnhardt and others (2001)) showing an eroding eddy sandbar capped by a coarsening-upward 1983 flood deposit. The initial sandbar surface after the 1983 flood is relatively coarse. Subsequent lateral erosion of the sandbar exposes the finer sand at progressively greater depths within the 1983 flood deposit.

tion and erosion rates in the eddies depending on the details of the flow fields in the eddies (Schmidt and others, 1993; Nelson and others, 1994, 2003; Nelson and McDonald, 1995; Rubin and others, 1998; Wiele and others, 1999). Analysis of aerial photographs (Schmidt and others, 2004) and sidescan-sonar data (Anima and others, 1998; Wong and others, 2003; Schmidt and others, 2007) indicate that eddy sandbars compose only about 12 percent of the riverbed area (sandbars compose somewhat greater than 60 percent of the eddies by area, which compose about 20 percent of the river by area). Despite covering a small percentage of the riverbed area, the eddy sandbars in Marble and upper Grand Canyons are the dominant storage environment for finer sand in the regulated postdam river (Hazel and others, 2006). Furthermore, the grain size of the surfaces of these eddy sandbars is the dominant multiyear regulator of suspended-sand transport under normal powerplant releases from Glen Canyon Dam.

\section{Acknowledgments}

Funding for this study was provided by the Bureau of Reclamation through the USGS Grand Canyon Monitoring and Research Center. This study was motivated by conversations with Randy Peterson (Bureau of Reclamation). Richard Wilson and Julie Graf (USGS) collected the September 1984 pipe-dredge data used in this study. Ted Melis and Steve Wiele (USGS) provided valuable input and help during the 1997-2000 fieldwork. Logistical support for fieldwork on the Colorado River in Grand Canyon was provided by Humphrey Summit Support. We would like to thank Amy Draut, Ted Melis, Jon Nelson, Ned Andrews, and Scott Wright for helpful reviews of earlier versions of this manuscript.

\section{References}

Andrews, E.D., 1990, The Colorado River; A perspective from Lees Ferry, Arizona, in Wolman, M.G., Church, M., Newbury, R., Lapointe, M., Frenette, M., Andrews, E.D., Lisle, T.E., Buchanan, J.P., Schumm, S.A., and Winkley, B.R., The riverscape, in Wolman, M.G., and Riggs, H.C., eds.: Boulder, Colorado, Geological Society of America, Surface Water Hydrology, The Geology of North America, v. O-1, p. 281-328.

Andrews, E.D., 1991, Sediment transport in the Colorado River basin, in Committee to Review the Glen Canyon Environmental Studies, Water Science and Technology Board, Commission on Geosciences, Environment, and Resources, eds.: Washington, D.C., National Academy Press, Colorado River Ecology and Dam Management, p. 54-74. 
Anima, R.J., Marlow, M.S., Rubin, D.M., and Hogg, D.J., 1998, Comparison of sand distribution between April 1994 and June 1996 along six reaches of the Colorado River in Grand Canyon, Arizona: U.S. Geological Survey Open-File Report 98-141, 33 p.

Barnhardt, W., Kayen, R., Rubin, D., and Minasian, D., 2001, The internal structure of sand bars on the Colorado River, Grand Canyon, as determined by ground-penetrating radar: U.S. Geological Survey Open-File Report $01-425$.

Beus, S.S., Biddle, J.W., Glass, M., Iaquinto, P., Lojko, F.B., and McAfee, B., 1983, Beach sand grain size on the Colorado River from Glen Canyon to Diamond Creek, in Students and Staff of Biology 571-Geology 538, instructors S.S. Beus and S.W. Carothers, Colorado River Investigations I, July-August 1982: Report submitted to Grand Canyon National Park, p. 20-27. Available at the USGS Grand Canyon Monitoring and Research Center, Flagstaff, Ariz.

Cooley, M.E., Aldridge, B.N., and Euler, R.C., 1977, Effects of the catastrophic flood of December, 1966, north rim area, eastern Grand Canyon, Arizona: U.S. Geological Survey Professional Paper 980, 43 p.

Dolan, R., Howard, A., and Gallenson, A., 1974, Man's impact on the Colorado River in the Grand Canyon: American Scientist, v. 62, p. 392-401.

Flynn, M.E., and Hornewer, N.J., 2003, Variations in sand storage measured at monumented cross sections in the Colorado River between Glen Canyon Dam and Lava Falls Rapid, northern Arizona, 1992-1999: U.S. Geological Survey Open-File Report 03-4104, 39 p.

Garrett, W.B., Van De Vanter, E.K., and Graf, J.B., 1993, Streamflow and sediment-transport data, Colorado River and three tributaries in Grand Canyon, Arizona, 1983 and 1985-86: U.S. Geological Survey Open-File Report 93-174, $624 \mathrm{p}$.

Hazel, J., Jr., Topping, D.J., Schmidt, J.C., and Kaplinski, M., 2006, Influence of a dam on fine-sediment storage in a canyon river: Journal of Geophysical Research, v. 111, F01025, 16 p., doi:10.1029/2004JF000193.

Howard, A.D., 1975, Establishment of benchmark study sites along the Colorado River in Grand Canyon National Park for monitoring of beach erosion caused by natural forces and human impact: University of Virginia Grand Canyon Study Technical Report no. 1, 182 p. Available at the USGS Grand Canyon Monitoring and Research Center, Flagstaff, Ariz.
Howard, A., and Dolan, R., 1981, Geomorphology of the Colorado River in the Grand Canyon: Journal of Geology, v. 89, p. 269-298.

Laursen, E.M., Ince, S., and Pollack, J., 1976, On sediment transport through Grand Canyon: Proceedings of the Third Federal Interagency Sedimentation Conference, p. 4-76 to 4-87.

Leopold, L.B., 1969, The rapids and the pools-Grand Canyon, in The Colorado River Region and John Wesley Powell: U.S. Geological Survey Professional Paper 669, 131-145 p.

Lojko, F.B., 1985, Beach sand grain size on the Colorado River in Grand Canyon, in Students and Staff of Geology 538-626 Northern Arizona University, under the supervision of S.S. Beus, and S.W. Carothers, edited by D.A. House, Colorado River Investigations III, July-August 1984: Report submitted to Grand Canyon National Park, p. 85-93. Available at the USGS Grand Canyon Monitoring and Research Center, Flagstaff, Ariz.

Lojko, F.B., 1987, Five year comprehensive study on beach sand grain size of the Colorado River in the Grand Canyon, in Students and Staff of Geology 538-626 Northern Arizona University, under the supervision of S.S. Beus, and S.W. Carothers, edited by G.C. Weiss, Colorado River Investigations V, July-August 1986: Report submitted to Grand Canyon National Park, p. 34-52. Available at the USGS Grand Canyon Monitoring and Research Center, Flagstaff, Ariz.

Lojko, F.B., Burmaster, B., Spears, G., Nelson, W., Dancis, D., and Byars, B., 1984, Beach sand grain size on the Colorado River in Grand Canyon, in Students and Staff of Geology 538-626, S.S. Beus, and S.W. Carothers, eds., Colorado River Investigations II, July-August 1983: Report submitted to Grand Canyon National Park, p. 49-57. Available at the USGS Grand Canyon Monitoring and Research Center, Flagstaff, Ariz.

Magirl, C.S., Webb, R.H., and Griffiths, P.G., 2005, Changes in the water surface profile of the Colorado River in Grand Canyon, Arizona, between 1923 and 2000: Water Resources Research, v. 41, W05021, 10 p.

McCutcheon, D.J., 1992, Size, shape, and composition of beach sand from selected sites in the Grand Canyon, in Students and Staff of Geology 601-Biology 680 Northern Arizona University, directed by S.S. Beus, J.N. David, F.B. Lojko, and L.E. Stevens, Colorado River Investigations XI, July-August 1992: Report submitted to Grand Canyon National Park, p. 139-155. Available at the USGS Grand Canyon Monitoring and Research Center, Flagstaff, Ariz. 
McKay, S., 1991, Beach grain sizes on two selected beaches in the Grand Canyon, in Students and Staff of Geology 601, Biology 680 Northern Arizona University, under the supervision of S.S. Beus, L.E. Stevens, and F.B. Lojko, Colorado River Investigations \#10, July-August 1991: Report submitted to Grand Canyon National Park, p. 56-65. Available at the USGS Grand Canyon Monitoring and Research Center, Flagstaff, Ariz.

McLean, S.R., 1992, On the calculation of suspended load for noncohesive sediments: Journal of Geophysical Research, v. 97 , p. $5759-5770$.

Melis, T.S., Webb, R.H., Griffiths, P.G., and Wise, T.J., 1994, Magnitude and frequency data for historic debris flows in Grand Canyon National Park and vicinity, Arizona: U.S. Geological Survey Water Resources Investigations Report 94-4214, 285 p.

National Research Council, 1996, River Resource Management in the Grand Canyon: Washington, D.C., National Academy Press, 226 p.

Nelson, J.M., Bennett, J.P., and Wiele, S.M., 2003, Flow and sediment-transport modeling, in G.M. Kondolf, and H. Piegay, eds., Tools in Fluvial Geomorphology: Chichester, West Sussex, England, John Wiley and Sons, Ltd., p. 539-576.

Nelson, J.M., and McDonald, R.R., 1995, Mechanics and modeling of flow and bed evolution in lateral separation eddies. Final report submitted to the USGS Grand Canyon Monitoring and Research Center, Flagstaff, Ariz., 39 p., http://www.gcmrc.gov/library/reports/GCES/Physical/ hydrology/Nelson1996.pdf, accessed April 8, 2008.

Nelson, J.M., McDonald, R.R., and Rubin, D.M., 1994, Computational prediction of flow and sediment transport patterns in lateral separation eddies: EOS, Transactions, American Geophysical Union, v. 75, p. 268.

Randle, T.J., and Pemberton, E.L., 1987, Results and Analysis of STARS Modeling Efforts of the Colorado River in Grand Canyon: NTIS report no. PB88-183421, U.S. Bureau of Reclamation Glen Canyon Environmental Studies Report, 41 p., http://www.gcmrc.gov/library/reports/physical/Fine_ Sed/Randle1987.pdf, accessed April 9, 2008.

Rubin, D.M., Nelson, J.M., and Topping, D.J., 1998, Relation of inversely graded deposits to suspended-sediment grainsize evolution during the 1996 flood experiment in Grand Canyon: Geology, v. 26, p. 99-102.

Rubin, D.M., Schmidt, J.C., Anima, R.A., Brown, K.M., Hunter, R.E., Ikeda, H., Jaffe, B.E., McDonald, R., Nelson, J.M., Reiss, T.E., Sanders, R., and Stanley, R.G., 1994, Internal structure of bars in Grand Canyon and evaluation of proposed flow alternatives for Glen Canyon Dam: U.S. Geological Survey Open-File Report 94-594, 56 p.
Rubin, D.M., Schmidt, J.C., and Moore, J.N., 1990, Origin, structure, and evolution of a reattachment bar, Colorado River, Grand Canyon, Arizona: Journal of Sedimentary Petrology, v. 60, p. 982-991.

Rubin, D.M., and Topping, D.J., 2001, Quantifying the relative importance of flow regulation and grain-size regulation of suspended-sediment transport $(\alpha)$, and tracking changes in bed-sediment grain size $(\beta)$ : Water Resources Research, v. 37, p. $133-146$.

Rubin, D.M., and Topping, D.J., in press, correction to "Quantifying the relative importance of flow regulation and grainsize regulation of suspended-sediment transport $(\alpha)$, and tracking changes in bed-sediment grain size $(\beta)$ by David M. Rubin and David J. Topping": submitted to Water Resources Research.

Rubin, D.M., Topping, D.J., Schmidt, J.C., Hazel, J., Kaplinski, K., and Melis, T.S., 2002, Recent sediment studies refute Glen Canyon Dam hypothesis: EOS, Transactions, American Geophysical Union, v. 83, p. 273 and 277-278.

Schmidt, J.C., 1990, Recirculating flow and sedimentation in the Colorado River in Grand Canyon, Arizona: Journal of Geology, v. 98, p. 709-724.

Schmidt, J.C., 1999, Summary and synthesis of geomorphoric studies conducted during the 1996 controlled flood in Grand Canyon, in R.H. Webb, J.C. Schmidt, G.R. Marzolf, and R.A. Valdez, eds., The 1996 Controlled Flood in Grand Canyon: Washington, D.C., American Geophysical Union, Geophysical Monograph 110, p. 329-342.

Schmidt, J.C., and Graf, J.B., 1990, Aggradation and Degradation of Alluvial Sand Deposits, 1965 to 1986, Colorado River, Grand Canyon National Park, Arizona: U.S. Geological Survey Professional Paper 1493, 74 p.

Schmidt, J.C., and Rubin, D.M., 1995, Regulated streamflow, fine-grained deposits, and effective discharge in canyons with abundant debris fans, in J.E. Costa, A.J. Miller, K.W. Potter, and P.R. Wilcock, eds., Natural and Anthropogenic Influences in Fluvial Geomorphology: The Wolman Volume: Washington, D.C., American Geophysical Union, Geophysical Monograph 89, p. 177-195.

Schmidt, J.C., Rubin, D.M., and Ikeda, H., 1993, Flume simulations of recirculating flow and sedimentation: Water Resources Research, v. 29, p. 2925-2939. 
Schmidt, J.C., Topping, D.J., Grams, P.E., and Hazel, J.E., 2004, System-wide changes in the distribution of fine sediment in the Colorado River corridor between Glen Canyon Dam and Bright Angel Creek, Arizona. Final report to the USGS Grand Canyon Monitoring and Research Center, Flagstaff, Ariz., 107 p., http://www.gcmrc.gov/library/ reports/physical/Fine_Sed/Schmidt2004.pdf, accessed April 9, 2008.

Schmidt, J.C., Topping, D.J., Rubin, D.M., Hazel, J.E., Jr., Kaplinski, M., Wiele, S.M., and Goeking, S.A., 2007, Streamflow and sediment data collected to determine the effects of Low Summer Steady Flows and Habitat Maintenance Flows in 2000 on the Colorado River between Lees Ferry and Bright Angel Creek, Arizona: U.S. Geological Survey Open-File Report 2007-1268, 79 p.

Stevens, L., 1983, The Colorado River in Grand Canyon: Flagstaff, Ariz., Red Lake Books, 115 p.

Topping, D.J., Rubin, D.M., and Melis, T.S., 2007, Coupled changes in sand grain size and sand transport driven by changes in the upstream supply of sand in the Colorado River: Relative importance of changes in bed-sand grain size and bed-sand area: Sedimentary Geology, 24 p., doi:10.1016/j.sedgeo.2007.03.016.

Topping, D.J., Rubin, D.M., Nelson, J.M., Kinzel, P.J., III, and Bennett, J.P., 1999, Linkage between grain-size evolution and sediment depletion during Colorado River floods, in Webb, R.H., Schmidt, J.C., Marzolf, G.R., and Valdez, R.A., eds., The 1996 Controlled Flood in Grand Canyon: Washington, D.C., American Geophysical Union, Geophysical Monograph 110, p. 71-98.

Topping, D.J., Rubin, D.M., Nelson, J.M., Kinzel, P.J., III, and Corson, I.C., 2000b, Colorado River sediment transport 2. Systematic bed-elevation and grain-size effects of sand supply limitation. Water Resources Research, v. 36, p. 543-570.

Topping, D.J., Rubin, D.M., and Schmidt, J.C., 2005, Regulation of sand transport in the Colorado River by changes in the surface grain size of eddy sandbars over multi-year timescales: Sedimentology, v. 52, p. 1133-1153, doi: 10.1111/j.1365-3091.2005.00738.x.

Topping, D.J., Rubin, D.M., and Vierra, L.E., Jr., 2000a, Colorado River sediment transport 1 . Natural sediment supply limitation and the influence of Glen Canyon Dam: Water Resources Research, v. 36, p. 515-542.

Topping, D.J., Schmidt, J.C., and Vierra, L.E., Jr., 2003, Computation and analysis of the instantaneous-discharge record for the Colorado River at Lees Ferry, Arizona-May 8, 1921, through September 30, 2000: U.S. Geological Survey Professional Paper 1677, 118 p, http://pubs.water.usgs.gov/ pp1677/, accessed April 9, 2008.
U.S. Department of the Interior, 1995, Operation of Glen Canyon Dam, Final Environmental Impact Statement: Salt Lake City, Utah, Bureau of Reclamation, 337 p.

Webb, R.H., Pringle, P.T., and Rink, G.R., 1989, Debris flows from tributaries of the Colorado River, Grand Canyon National Park, Arizona: U.S. Geological Survey Professional Paper 1492, 39 p.

Webb, R.H., Schmidt, J.C., Marzolf, G.R., and Valdez, R.A., eds., 1999, The 1996 Controlled Flood in Grand Canyon: Washington, D.C., American Geophysical Union, Geophysical Monograph 110, 367 p.

Wiele, S.M., Andrews, E.D., and Griffin, E.R., 1999, The effect of sand concentration on depositional rate, magnitude, and location in the Colorado River below the Little Colorado River, in Webb, R.H., Schmidt, J.C., Marzolf, G.R., and Valdez, R.A., eds., The 1996 Controlled Flood in Grand Canyon: Washington, D.C., American Geophysical Union, Geophysical Monograph 110, p. 131-145.

Wiele, S.M, Graf, J.B., and Smith, J.D., 1996, Sand deposition in the Colorado River in the Grand Canyon from flooding of the Little Colorado River: Water Resources Research, v. 32, p. 3579-3596.

Wong, F.L., Anima, R.J., Galanis, P., Codianne, J., Xia, Y., Bucciarelli, R., and Hamer, M., 2003, Grand Canyon riverbed sediment changes, experimental release of September 2000; A sample dataset: U.S. Geological Survey Open-File Report 03-0265. 
This page intentionally left blank 


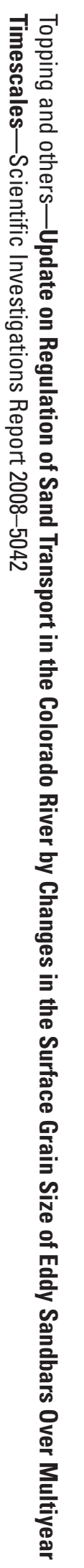

